\title{
Expectativas e impasses dos sulistas norte-americanos no Estuário do Prata: a questão da navegação dos rios e a viagem do comandante da U.S. Navy - Thomas Jefferson Page (1853-1860)
}

\section{Marília Arantes Silva Moreira ${ }^{1}$}

\section{Resumo}

$\mathrm{O}$ artigo discute os interesses dos sulistas dos Estados Unidos em relação à América do Sul, através do estudo da expedição do navio a vapor Water Witch, realizada pelo comandante da U.S. Navy, Thomas Jefferson Page, pelo rio da Prata e adjacentes. Com poderes para realizar, na região, trabalhos científicos e diplomáticos para negociar em favor da livre navegação dos rios, além de estabelecer tratados comerciais, Page entrou em conflito com o governo do Paraguai, durante a qual o navio foi bombardeado. Em resposta, os Estados Unidos aprovaram uma intervenção no Paraguai, em 1858. Tal realização movimentou navios e canhões, para restituir acordos comerciais e viabilizar a segunda - e conclusiva - etapa da expedição de Page, entre 1858-60. O artigo pretende mostrar que parte dos objetivos dos norteamericanos foram alcançados na região, ainda que tenham usado a força para fazer valer as suas intenções, principalmente, no Paraguai.

Palavras-chave: Estados Unidos, Rio da Prata, Navegação dos rios

\begin{abstract}
The article discusses the interests involved in the expedition made by the U.S Navy commander Thomas Jefferson Page, through "La Plata, the Argentine Confederation and Paraguay" (1853-1860). With diplomatic powers to persuade free river navigation in South America, Page obtained consents for his transit and cartographic work especially by the Empire of Brazil and the Argentine Confederation. However, a conflict with the government of Paraguay has resulted in a dispute with the country's president, Carlos Antonio López. In response, the U.S. Congress approved in 1858 the moving of ships and cannons to settle up commercial agreements and enable a second and conclusive part of the expedition (1858-60). The article demonstrates that part of the North-American objectives were reached, despite they have used military force for constraining local governments, like the Paraguayan.

\footnotetext{
1 Mestre em Relações Internacionais pela Universidade de São Paulo (Brasil). E-mail: marilia.arantes@gmail.com .
}

Revista Eletrônica da ANPHLAC, ISSN 1679-1061, n.15, p. 79-112, jul./dez. 2013. http://revista.anphlac.org.br/ 
Keywords: United States, La Plata basin, River navigation

Artigo recebido em: 30/06/2013

Artigo aprovado em: 18/08/2013

\section{Expectativas da viagem: em nome do comércio.}

O objetivo deste artigo é discutir os interesses dos Estados Unidos na América do Sul - mais precisamente no espaço que compreende o rio da Prata e seus adjacentes — através da expedição realizada pela Marinha de Guerra dos Estados Unidos, a U.S. Navy, sob o comando do sulista Thomas Jefferson Page, entre 1853 e 1860. Para tal, apresentamos a viagem propriamente dita e os percalços enfrentados pelos norte-americanos que desejavam navegar pelos rios da região, imaginando que teriam livre acesso para implantar seus projetos e atividades nessa parte da América ${ }^{2}$. Para tanto, utilizamos, além do relato de viagem do comandante, cartas, documentos oficiais, que nos permitem reconstruir o trajeto da viagem, os objetivos a serem alcançados, os conflitos com os quais se viram envolvidos e, por fim, mostramos que apenas parte dos objetivos foram alcançados ${ }^{3}$.

No contexto do debate internacional sobre a navegação dos rios, ideias de progresso e neutralidade da ciência - conforme uma cultura imperial, também em voga nos Estados Unidos, e em países europeus - impulsionaram a vinda de certo grupo sulista à região. A expedição carregava objetivos explícitos, como a realização de trabalhos científicos de cartografia, por exemplo. Buscavam a interconexão entre a bacia do Prata e a do Amazonas e coletas de espécimes da região, assim como também o estabelecimento de tratados comerciais com os países da América do Sul.

Entretanto, havia ainda objetivos implícitos, pouco aventados na documentação oficial. Nessa época, nos Estados Unidos, os sulistas dominavam

\footnotetext{
${ }^{2}$ Aqui, sigo as perspectivas colocadas por intelectuais, que afirmam a existência de uma cultura imperial por parte dos Estados Unidos, na qual se buscava forjar um discurso de autoridade dos norteamericanos enquanto "centro de saber" sobre os demais países. Ver: SAID (1995); SALVATORE (1998; 2006).

${ }^{3} \mathrm{O}$ documento central à pesquisa é o relato de viagem: PAGE (1871 - Traduções do original pela autora). Cartas, ofícios e outros documentos oficiais foram publicados, conforme PAGE (1856). Ainda incluem-se documentos oficiais e extraoficiais da Bolívia, Peru, Argentina, Brasil, Paraguai, Uruguai, Chile e dos Estados Unidos.
}

Revista Eletrônica da ANPHLAC, ISSN 1679-1061, n.15, p. 79-112, jul./dez. 2013. http://revista.anphlac.org.br/ 
importantes cargos na administração pública do país e comandavam a U.S. Navy. Matthew Fontaine Maury, a quem me remeterei aqui diversas vezes, concentrava politicamente as novas perspectivas almejadas por seu grupo de interesses. Ele e outros sulistas - Thomas Jefferson Page inclusive - desejavam a possibilidade de transferência de famílias sulistas com os seus escravos, para espaços pouco habitados, caso a escravidão viesse a ser abolida no país ou estourasse uma guerra civil entre norte e sul, conforme alguns supunham que iria ocorrer. A região do rio Amazonas e outras possíveis regiões da América do Sul estavam entre aquelas sob a mira norteamericana para esse fim.

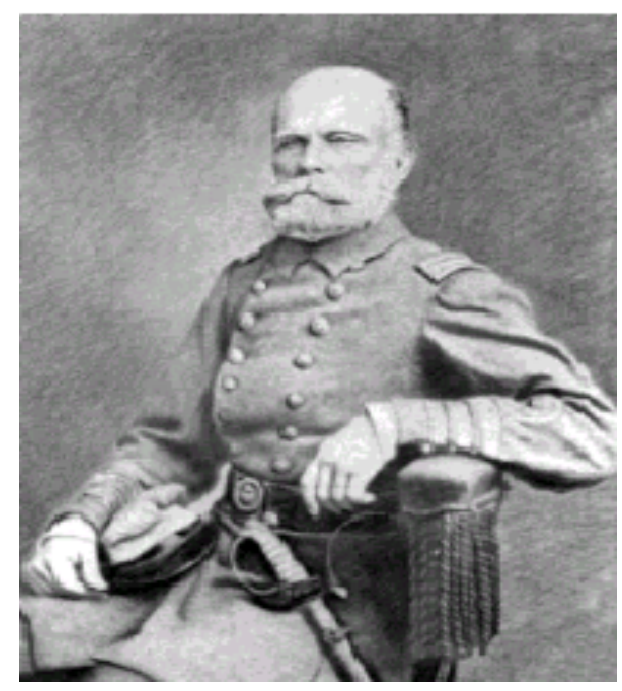

Thomas Jefferson Page

(The Buenos Aires Herald, 2003)

Nascido na Virginia, em um meio social "ilustrado" - atualizado por tendências europeias - Thomas Jefferson Page pertencia a uma "aristocracia sulista", com a qual ele, notadamente, se identificava. Por exemplo, seu avô, Nelson Page, foi signatário da constituição norte-americana e muito próximo do presidente Thomas Jefferson (1801-1809) ${ }^{4}$.

T.J. Page entrou para os quadros na U.S. Navy como protegée (afilhado) de Matthew Fontaine Maury, seu conterrâneo, influente oficial e cientista, superintendente do Observatório Naval em Washington, no período da administração sulista da U.S. Navy (1842-61). Além disso, ele foi chefe do Departamento de

\footnotetext{
${ }^{4}$ A utilização do termo aristocracia é questionável quando se refere à história das Américas. Contudo, era utilizado pela classe social em questão. O próprio irmão de Page intitulou um livro sobre seu tio, Nelson Page, como Memórias de um aristocrata sulista.
}

Revista Eletrônica da ANPHLAC, ISSN 1679-1061, n.15, p. 79-112, jul./dez. 2013. http://revista.anphlac.org.br/ 
Cartografia e Instrumentos e criou o Mapa das correntes e ventos do Atlântico norte (1853), que ainda permanece como referência para a navegação. Entretanto, propôs também teorias polêmicas como em Geografia física dos mares e sua meteorologia (1855), na qual procurava demonstrar que alguns continentes poderiam ser contíguos em razão de correntes e ventos, como veremos a seguir.

Maury indicou Page como comandante do navio a vapor Water Witch, em 1853, para a realização de trabalho no estuário do Prata, na América do Sul ${ }^{5}$. Seguem as instruções oficiais para a viagem de Page publicadas no relato da expedição:

Os principais objetivos de sua atenção [de Page] serão prospectar os rios da Prata, Paraguay e Parana, todos os adjacentes que valham exploração, para determinar a possibilidade de navegá-los, seus cursos, extensão, produção pesqueira etc.; examinar não somente os países limítrofes destes rios, mas também algumas extensões do interior além das margens, de forma a adquirir informações precisas sobre a natureza e agricultura locais, e consequentemente, a probabilidade de até onde o intercâmbio comercial possa ser desejável; fazer coleções para o avanço do conhecimento em história natural, botânica, mineralogia, e outros setores das ciências naturais; observações astronômicas, meteorológicas e magnéticas; determinar latitudes e longitudes e fazer uma série de esboços e impressões ilustrativas com o Daguerreótipo do cenário, dos índios e das formações geológicas do país. (PAGE, 1871, Appendix A, p.567)

Assim, em 1853, o vapor Water Witch zarpou de Norfolk, rumo à América do $\mathrm{Sul}^{6}$. Page e uma equipe de 56 oficiais passaram rapidamente pelo Rio de Janeiro e Montevidéu, antes de seguir para Buenos Aires, em 1853. Entre os principais oficiais, constavam os tenentes William Murdaugh, William Powell, Daniel Ammen, o cirurgião Robert Carter, o engenheiro Allen Campbell e T.B.C. Stump, assistente de engenharia.

O navio carregava equipamentos de alta tecnologia: instrumentos para medir latitudes, longitudes e medições conjugadas com observações do sol e das estrelas. Cinco cronômetros foram selecionados por Maury, que, de antemão, apurou a acurácia de cada um. Além disso, trazia três potentes canhões Howitzers, que, como veremos, foram armas utilizadas em razão de contendas abertas entre Page e o

\footnotetext{
${ }^{5} \mathrm{Na}$ listagem do Centro de História Naval da U.S. Navy, em Washington, na carreira de "Page, Thomas J.", constam as seguintes etapas: guarda-marinha, $1^{\circ}$ outubro, 1827; primeiro-tenente, 10 de junho, 1833; segundo-tenente, 20 de dezembro, 1839; capitão de fragata, 14 de setembro, 1855. Dispensado, 22 de abril, 1861. Sabe-se que Page serviu no Caribe e comandou o USS Plymouth, em 1849, nos mares da China e do Japão.

6 "Water Witch", em inglês, literalmente, significa "bruxa das águas". No entanto, é também uma expressão para definir a busca por nascentes e minas de água. Na forma verbal, "Water witching" significa "procurando minas de água".
}

Revista Eletrônica da ANPHLAC, ISSN 1679-1061, n.15, p. 79-112, jul./dez. 2013. http://revista.anphlac.org.br/ 
Paraguai ${ }^{7}$.

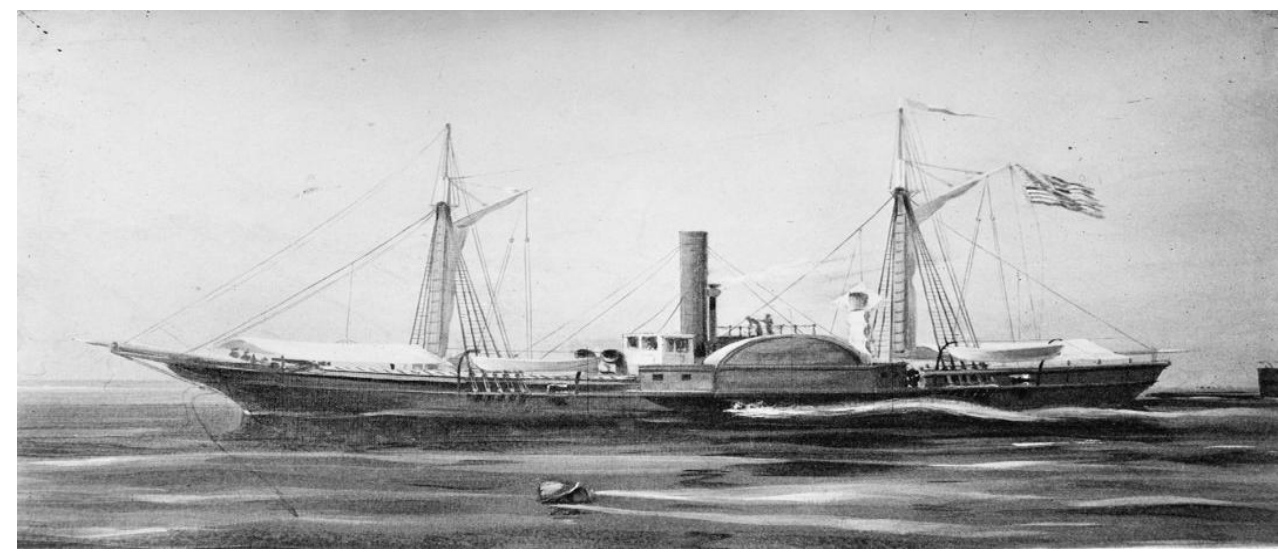

O navio a vapor Water Witch (Imagem: Biblioteca do Congresso Norte-Americano).

Nos primeiros anos da viagem, Page cumpriu distintos planos de ação. Os homens se dividiam em trabalhos semelhantes de cartografia e verificação em rios diferentes, mas próximos um do outro, além das expedições por terra ${ }^{8}$. Assim, eles prospectaram os rios Uruguay, Tercero, Salgado (Salado), Vermelho (Bermejo) e Pilcomayo. Os espécimes da fauna e flora nativa foram enviados, ao longo da viagem, para catalogação, compondo o acervo do Smithsonian Institute, em Washington ${ }^{9}$.

No documento a seguir (um apêndice do relato oficial), o secretário da U.S. Navy, William Graham, em 1852, justificou a expedição ao American Geographical and Statistical Society, um braço decisório da Secretaria da Marinha no século XIX:

A maioria das grandes explorações comerciais e científicas dos últimos cem anos foi conduzida por oficiais de Marinha, sob o patrocínio de seus respectivos governos. Inglaterra, França, Holanda, Rússia e Estados Unidos têm nomes nas listas navais que reuniram os mais brilhantes louros dos campos pacíficos de trabalhos de pesquisa. Nosso próprio governo tem se destacado por admiráveis levantamentos de mares e costas, como nas expedições à Antártida e ao Ártico e agora dirige atenção ao Japão. No caso desta expedição mencionada por último [ao Japão], possivelmente seja necessário fazer uso da força para obtermos sucesso. Mas, na presente proposição ao Departamento, para se explorar o rio da Prata, o elemento força não será necessário. Enviaremos o pequeno navio para onde nunca se

\footnotetext{
${ }^{7}$ Canhões Howitzers eram, no período, uma inovadora e potente artilharia à pólvora, depois utilizados na Guerra Civil norte-americana (1861-1865).

${ }^{8} \mathrm{Na}$ equipe, constavam especialistas em construção de pequenas embarcações. Com materiais retirados no local, madeira principalmente, montavam modelos específicos, de baixo calado, apropriados para percorrerem afluentes e alagadiços de profundidades variáveis.

9 O Smithsonian Institution foi fundado em 1846, com a função de "difundir o conhecimento". Expedições como a de Page serviram para reunir coleções e formar acervos, que aparelharam museus nacionais para competir com demais instituições e potências - especialmente, tinham como referência o British Museum de Londres.
}

Revista Eletrônica da ANPHLAC, ISSN 1679-1061, n.15, p. 79-112, jul./dez. 2013. http://revista.anphlac.org.br/ 
viu um deles antes, será bem-vindo por uma população entusiasmada e recebido com gratidão. (PAGE, 1871, p.599, grifo meu)

Durante a administração dos poderosos sulistas, investiu-se no conhecido Program of Naval Rejuvenation, projeto que lançou viagens científico-estratégicas, ampliando influências sobre a U.S. Navy. A política executada por M.F. Maury, marcou a presença norte-americana na corrida pelo mapeamento do globo, inserindo os Estados Unidos - que buscavam "ganhar um lugar no mundo" -, no esforço internacional de constituição dos sistemas de longitudes, cartas náuticas e mapas, como aponta a historiadora Mary Anne Junqueira $(2008)^{10}$. No entanto, os norteamericanos, buscavam autonomia ao superar a precisão científica das potências europeias (Grã-Bretanha, Espanha, França e Rússia), dando origem a um sistema cartográfico próprio.

Pelo corpo da U.S. Navy, eles determinaram esquadras de expansão geopolítica que os colocaram em pontos estratégicos. Expedições de grande envergadura, oficiais e científicas, tinham finalidade de conhecer, mapear e apreender novas possibilidades, principalmente, para dominarem fluxos comerciais em disputa na Ásia e no Pacífico. Mas a América Latina, na primeira metade do século XIX, também concentrou grandes interesses norte-americanos, com exceção dos anos em que estiveram em guerra contra o México (1846-48). Ao total, doze expedições da U.S. Navy destinaram-se à região. Entretanto, com a Guerra Civil norte-americana (1861-1865) e a busca pela construção de um canal para o Pacífico, esforços geoestratégicos passaram a se concentrar na América Central (JUNQUEIRA, 2008).

Conforme Page (1871) menciona na introdução da narrativa, ele esperava ser nomeado para uma missão nos mares do Japão e Oceano Pacífico. Todavia, embora manifestasse desagrado em servir na América do Sul e não em águas da Ásia, ele compartilhou ter aceitado o comando da expedição pelo rio da Prata, dando a entender que a missão seria menos arriscada, ou mais garantida. Porém, como demonstraremos, não foi bem isso o que aconteceu. Na verdade, Page ressentia-se de não ter sido convocado para a grande viagem exploratória ao Japão, que ficou conhecida por ter aberto as portas daquele país da Ásia ao ocidente. Ao invés de Page — relegado a uma viagem de importância menor ao Estuário do Prata - Matthew C. Perry levou os

\footnotetext{
10 "Na primeira metade do século XIX, com o objetivo de garantir o livre fluxo de mercadorias e navios norte-americanos pelos mares, o governo dos Estados Unidos estabeleceu as seguintes esquadras alémmar: Mediterrâneo (1815), Índias Ocidentais (1822), Pacífico (1821), Brasil - ou Atlântico Sul - (1826), Índia (Ásia - 1835), Esquadra doméstica (1841)"(JUNQUEIRA, 2008, p.122-124).
}

Revista Eletrônica da ANPHLAC, ISSN 1679-1061, n.15, p. 79-112, jul./dez. 2013. http://revista.anphlac.org.br/ 
louros, em razão do sucesso alcançado com sua investida nos mares da Ásia, na década de 1850, em particular, em razão da abertura das portas do Japão às nações ocidentais.

\section{Projetos dos sulistas norte-americanos na Amazônia}

Como já indicamos, Matthew Fontaine Maury articulou estabelecer um "grande império do comércio e da ciência" ao Sul do continente americano ${ }^{11}$. Imaginava uma "República Amazônica" - área de novas plantations - formada como território dependente aos Estados Unidos, para transferência de famílias agricultoras, junto aos seus escravos à região. Esse assunto bem trabalhou a historiadora Nícia Luz, em A Amazônia para os Negros Americanos (1968).

Nesse contexto, em 1851, a U.S. Navy empreendeu uma expedição pela região Amazônica, realizada pelos oficiais William Herndon (cunhado de Matthew Maury) e Lardner Gibbon, em dois trajetos distintos ${ }^{12}$. Por fim, ambos procederam à travessia do rio Amazonas. Contudo, segundo relataram, enfrentaram em diversas situações uma grande "hostilidade" da natureza, que o termo wilderness explica bem ${ }^{13}$.

Notavelmente, a viagem de Page no Prata dava sequência à prospecção do Amazonas. Entre diversos interesses, pretendiam manter um status quo e sondavam terras férteis para cultivarem lavouras, principalmente, de tabaco e algodão (PAGE, 1871$, p.432) $)^{14}$.

Por um lado, a teoria abraçada por Maury e outros defendia que o sistema de correntes e ventos fazia com que o sistema de rios do Amazonas tivesse vinculação com o sistema do rio Mississippi, o que poderia garantir a presença norte-americana no norte da América do Sul. Por outro, um dos objetivos de T.J. Page, como veremos, era verificar as conexões entre as duas grandes bacias hidrográficas do continente, a do Prata e do Amazonas. Se elas existissem, possivelmente estariam também

\footnotetext{
${ }^{11}$ Sobre o projeto de expansão sulista para além das fronteiras nacionais, ver: SAMPAIO (2009, p. 8687).

${ }^{12}$ Eles navegaram segundo as instruções privilegiadas que receberam para introduzirem embarcações a vapor, evitando-se quedas d'água; da boca do rio Madeira (Peru) subiram a cordilheira dos Andes, contornando a Bolívia rumo ao Amazonas pelo Mamoré, em direção ao Atlântico.

${ }^{13}$ Sobre o conceito de wilderness, ver JUNQUEIRA (2000).

${ }^{14}$ É interessante pontuar que o botânico francês Aimé de Bonpland, companheiro do naturalista alemão Alexander Von Humbolt em expedição pela América, exilou-se no interior da Argentina fugindo do presidente José Gaspar Rodrígues Francia, do Paraguai. Ele manteve correspondências com Page e recebeu o tenente Murdaugh, que buscava informações sobre terras mais propícias à plantação de algodão no Grande Chaco. Bonpland avaliou que o Paraguai era muito apropriado, mas Corrientes, na Argentina, não. Exatamente nessa região firmou-se um acordo de colonização com o governo local, em 1853, envolvendo também interessados de demais nacionalidades (PAGE, 1871, p.591-593).
}

Revista Eletrônica da ANPHLAC, ISSN 1679-1061, n.15, p. 79-112, jul./dez. 2013. http://revista.anphlac.org.br/ 
vinculadas ao Mississippi, central ao território dos Estados Unidos. Logo, o trabalho do sulistas seria “facilitar" este fluxo, sempre com intuitos comerciais ${ }^{15}$.

Assim, nesse período, os interesses dos Estados Unidos na América do Sul incluíam ainda a viagem do comandante e cientista, James Melville Gillis, que rumou para o Chile, com o objetivo de instalar um observatório astronômico na região. A viagem, entre 1849 e 1852, além dos objetivos científicos, especialmente do estabelecimento de dados astronômicos para a correta localização em alto mar, fez com que o comandante produzisse vários relatos sobre os países da América do Sul pelos quais viajou.

Expedições da U. S. Navy para a América do Sul (década de 1850)

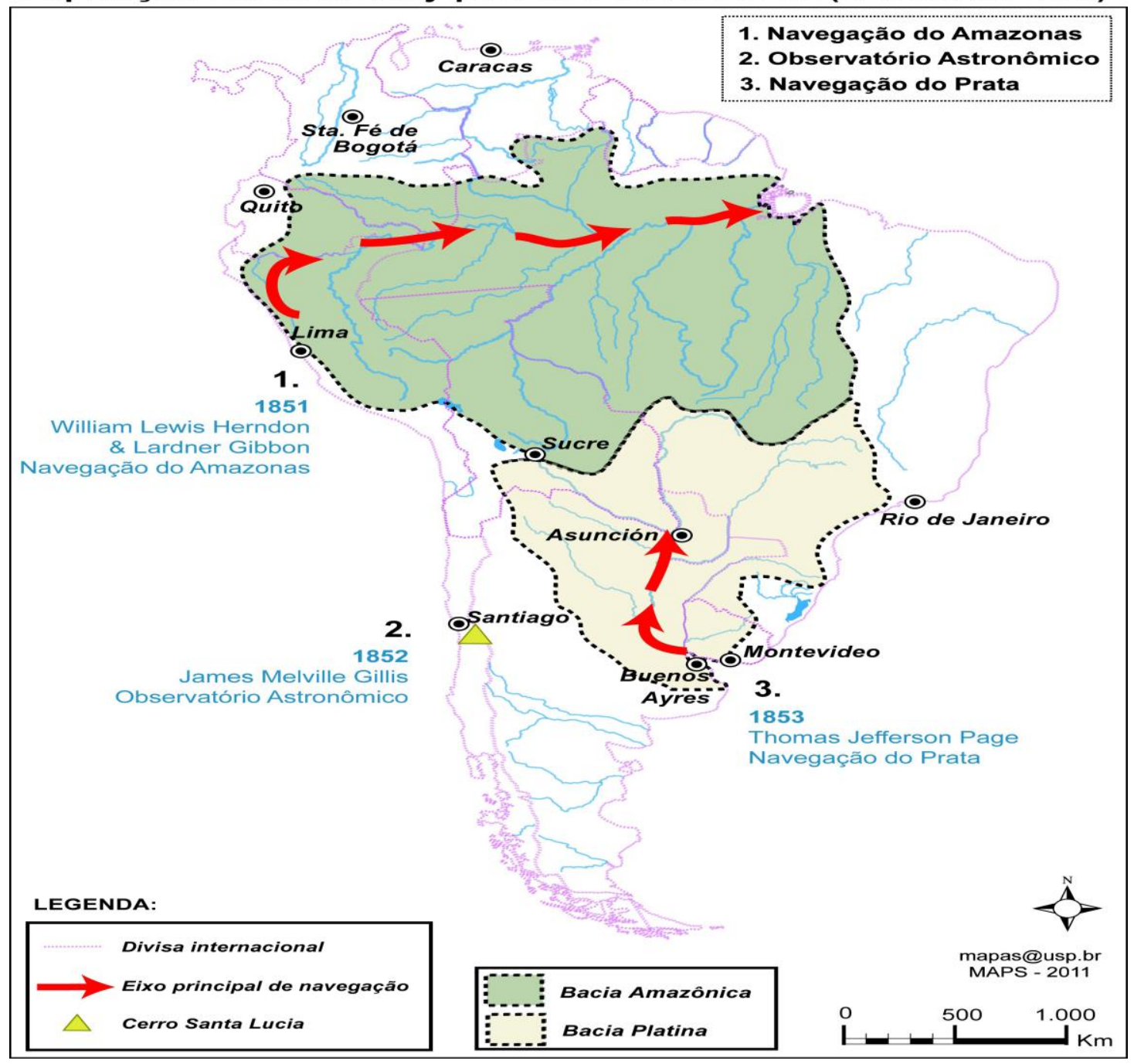

Enquanto isso, a partir de 1850, em disputa por influência regional, a defesa

\footnotetext{
${ }^{15}$ Desde os desfechos da independência, o tema da navegação se destacava nas discussões sobre os rios norte-americanos, como Mississippi e São Lourenço, e sobre a Lei das Nações. Em casos específicos, conferências envolveram, primordialmente, Grã-Bretanha, França e Espanha. Após o Tratado de Ghent (1814) e fortalecimento da U.S. Navy, os rios passaram à jurisdição norte-americana.
}

Revista Eletrônica da ANPHLAC, ISSN 1679-1061, n.15, p. 79-112, jul./dez. 2013. http://revista.anphlac.org.br/ 
brasileira já pretendia impor-se aos vizinhos através da Marinha do Brasil. Como não podia deixar de ser, negaram de imediato a proposta formal feita pelos sulistas, entre 1850-51, para a navegação no Amazonas. Expectativas norte-americanas despertaram o protecionismo diplomático brasileiro quanto à presença internacional (SAMPAIO, 2009, p. 87). Como definem Amado Cervo e Clodoaldo Bueno (CERVO; BUENO, 2009, p. 109), no período entre 1851 e 1864, a política de "presença brasileira ativa" respondeu à ameaça estrangeira pela integridade do Império, principalmente a dos norte-americanos na Amazônia.

No entanto, Maury estava convencido a pressionar o Brasil, reivindicando o direito à navegação do Amazonas, o "Mississippi do hemisfério sul”. Afinal, como ele afirmava, "A posição geográfica e tudo mais conspira à predominância do comércio norte-americano na região" (1854, p. 12). Na importante Convenção de Memphis, em 1853, promissoras oportunidades convenceram também aos oficiais responsáveis pela tomada de decisões na U.S. Navy (WHEATON, 1866, p. 44) ${ }^{16}$. De acordo com Maury, em discurso nessa Conferência;

Uma canalização natural para conectar as águas do rio Amazonas à do Prata está tão próxima de completar-se que, segundo as observações de exploradores, precisamos apenas três léguas de um canal artificial para passarmos navios de um rio para outro. A colonização pode cumprir objetivos de realizar os primeiros esforços, então viraríamos completamente o curso do "Mississippi do hemisfério Sul", traçando uma linha desde a boca [entrada da navegação] do Prata, no paralelo $36^{\circ} \mathrm{Sul}$, submetendo-a à prática comercial. Sob esta linha, toda a riqueza do Estuário do Prata, somada à do Amazonas, será despejada no nosso colo. (INGERSOLL, 1854, p.34) $^{17}$

\footnotetext{
${ }^{16}$ Reacendeu-se a questão conforme na Europa, em 1853, eclodiu a Guerra da Criméia, envolvendo principais potências navais. $\mathrm{O}$ debate sobre a livre navegação dos rios veio à tona ao final das Guerras Napoleônicas (Tratado de Paris, 1814); a partir da navegação rio Reno definiu-se a proposição do Tratado de Viena, de abertura às saídas para o mar (Art. 108, Navegação dos Rios). Posterior aplicação dos "princípios gerais" das potências signatárias - Áustria, Grã-Bretanha, Prússia e Rússia -, e replicação do comum acordo entre países ribeirinhos (“A menos que qualquer um se oponha em circunstâncias particulares sobre cursos de navegação que separem Estados distintos.") seguiu-se ao rio Scheldt (Antuérpia), Meuse, Moselle, Elbe, Oder, Weser e Pó, incluindo adjacentes. A livre navegação do Danúbio definiu-se na Guerra da Crimeia (1855). Na circunstancial obstrução do Mar Negro, retomou-se a questão da saída para o mar (como direito natural, com consentimento mútuo entre "coproprietários" e distinção do direito de passagem). Wheaton observa; "O princípio sobre o qual incide o direito de navegação depende dos mares que um rio una (...)". Dentre 1853 e 1855, sulistas de Maury dialogavam nesses termos. Adaptaram "mares" por "oceanos", Atlântico e Pacífico. (WHEATON, 1866, p.156).

${ }^{17}$ Por causa do impasse no Paraguai, em 1855, Maury articulou a intervenção nesse país, que acabaria sendo autorizada pelo Congresso, em 1858. Apoiando-se sobre a Lei das Nações, sua justificativa pautou-se por duas regras do direito internacional, em debate à época: 1) o rio da Prata tem proporção continental, logo sua navegação deve ter uso comum, tanto a Estados limítrofes como nações marítimas em geral; 2) quando atacado, o Water Witch encontrava-se na margem argentina do Paraná, portanto, o Paraguai não poderia reivindicar jurisprudência exclusiva. (Observa-se, porém, que a
}

Revista Eletrônica da ANPHLAC, ISSN 1679-1061, n.15, p. 79-112, jul./dez. 2013. http://revista.anphlac.org.br/ 
Por meio de avanços científicos, tais sulistas buscaram beneficiar interesses norte-americanos ao explorarem a região. No entanto, para fundar vias fluviais, deveriam construir canais que facilitassem o percurso das embarcações. Isso explica a participação de engenheiros na expedição. Além disso, Maury chegou a fundamentar uma vontade divina, ou um "destino" migratório, dado pela Providência e em razão do nível de civilização do norte (BOURNE, 1849) ${ }^{18}$. Ainda na Conferência de Memphis (1853), ele defendeu que

Os grandes mercados do mundo e os centros comerciais por todos os tempos estarão no hemisfério norte. Quatro quintos das terras secas do mundo estão nele. É o berço do conhecimento, das riquezas, da civilização e do empreendedorismo. A logística naval do mundo pertence a ele, também os navegantes. E a beneficência da Providência arranjou as estações de forma tão perfeita que quando é tempo de semear no hemisfério norte, no sul é exatamente a hora da colheita. (INGERSOLL, 1854, p.33)

Todavia, diferentemente da posição defensiva na Amazônia, o Império do Brasil jogou com os interesses estrangeiros no Prata, apoiando os sulistas, por exemplo, para desimpedir o acesso contínuo à província de Mato Grosso (Corumbá), pelo rio Paraguay. No entanto, termos da navegação local estavam ainda por ser definidos entre nações da região. $\mathrm{O}$ duplo posicionamento quanto à abertura causaria um "dilema moral” ao Império, como analisaremos à frente (PALM, 2009).

\section{O debate acerca da navegação dos rios.}

A operação liderada por Page em direção ao Prata deve ser compreendida em um contexto, no qual os sulistas buscavam lugares possíveis para transferência de famílias e escravos; eles percebiam a América do Sul como alternativa para um projeto de colonização (PAGE, 1871) ${ }^{19}$. Além disso, a expedição de Page deve ser

posição do navio era questionável). Outra alegação de Maury em defesa da abertura do rio à navegação estaria relacionada ao bloqueio do Mediterrâneo por causa da Guerra da Crimeia; 3) não se pode obstruir uma passagem, quando o ponto em questão interliga dois mares. Ele argumentou que o rio Amazonas cruzava um continente interligando o Atlântico e o Pacífico, tanto na Conferência de Memphis (1853), como em 1855, perante o Congresso norte-americano.

${ }^{18}$ Seguindo a tendência, os britânicos investiram na exploração do interior indiano, colônia crucial ao seu império, buscando ampliar o fluxo do comércio intercontinental ao caminho da China e demais regiões, com vias de acesso pelos rios.

${ }^{19} \mathrm{O}$ relato de Page (1871) apresenta em apêndice o Contrato de Colonização, firmado entre a província de Corrientes (capitão-general Don Juan Pujol) e o misterioso agente e organizador francês Augusto Brouges, de Caixon (este não aparece mais no relato). Descreve-se o projeto de transferência de 1.000 famílias agricultoras, detalhadamente. Cada família deveria compor-se de cinco pessoas; a maior parte,

Revista Eletrônica da ANPHLAC, ISSN 1679-1061, n.15, p. 79-112, jul./dez. 2013. http://revista.anphlac.org.br/ 
compreendida também em meio ao debate sobre a possibilidade de navegação nos rios, em razão do incremento da navegação a vapor, o que facilitava às embarcações subirem contra a correnteza, sem a necessidade dos ventos essenciais para navegação à vela ${ }^{20}$.

Nota-se que o debate sobre a navegação internacional reflete uma predominância eurocêntrica nas diretrizes das relações internacionais no século XIX. A questão passava pelo referencial Tratado de Viena (1818), que reafirmou a Lei das Nações com as resoluções do fim das Guerras Napoleônicas. Graças a uma proposta do governo francês, abriu-se a navegação do rio Reno aos países signatários. Pelo tratado, a livre navegação voltava-se a navios mercantes, sendo que taxas de trânsito não poderiam ser aumentadas sem a anuência de todos os países ribeirinhos. Com isso, buscava-se evitar o aumento descabido de impostos como obstáculos à livre navegação do rio (GREGÓRIO, 2010, p.153).

No "resto do mundo", questões de soberania e jurisprudência logo concentrariam desentendimentos. Embora, geralmente, o modelo da Revolução Francesa tenha garantido o direito privado nos Estados em formação, o direito internacional constituiu-se na prática. Para Lauren Benton (2001), as relações marítimas entre as potências europeias estabeleceram uma espécie de Império Informal, repercutindo novos padrões de organização, governamentais e jurídicos. Os ajustes entre potências do sistema internacional conformaram-se durante a exploração e disputas além-mar, particularmente, na Ásia, China, Índia, África e na América do Sul (BENTON, 2001).

Assim, permissões para navegação foram amplamente utilizadas como barganha política pelos países, tanto em relações regionais, quanto com as potências,

\footnotetext{
homens aptos ao trabalho, em idade acima de 10 anos (abaixo disso, considerar-se-iam "supernumerários"). A chegada de grupos de 200 famílias, em dez etapas, receberia amparo logístico da província. Cada grupo formaria uma colônia, nas locações oferecidas nas Missões, região entre rios Parana e Uruguay, em lotes selecionados por Brouges dentre as "terras públicas". Com "Veinte cuadras quadradas de ciento cinquenta vases por cada lado", a província providenciaria casas de madeira ("dois quartos, uma porta, uma janela") com seis barris de farinha, sementes de tabaco e algodão "suficiente para uma quadra", "fanegas" (sementes) de trigo e milho e mudas de cana de açúcar, doze cabeças de animais ("dois touros, oito vacas e dois cavalos"). Em três anos, deveriam "devolver" o investimento, conforme a chegada dos novos grupos. Plantariam algodão, tabaco, açúcar, trigo e milho. Estariam sob as leis da província, embora dispensados do serviço militar. Nos primeiros cinco anos, teriam isenção de impostos. Depois, os lotes se tornariam "propriedade absoluta de cada família" (p. 591-593).

${ }^{20}$ A engenharia naval norte-americana especializou-se no design de barcos à travessia de rios. Os EUA discutiram, principalmente, a navegação do Mississippi com a Espanha, no século XVIII, e a do rio São Lourenço, no Canadá, no século XIX, com Grã-Bretanha. Tais resoluções - conferências específicas às circunstâncias - inspiraram-se na Lei das Nações.
}

Revista Eletrônica da ANPHLAC, ISSN 1679-1061, n.15, p. 79-112, jul./dez. 2013. http://revista.anphlac.org.br/ 
mediante assimetria de poder. Na América do Sul, enquanto o Império do Brasil e a Confederação Argentina permitiram que Page navegasse por determinados rios, o acesso foi negado pelo Paraguai, o que não quer dizer que o Brasil permitisse a livre navegação: permitia em alguns trechos e restringia em outros. As autorizações eram negociadas em acordos bilaterais de cooperação, conforme os interesses em jogo (WHEATON, 1866) $)^{21}$.

Como apresenta o historiador Paulo Roberto Palm (2009), em A abertura do rio Amazonas à navegação internacional e o Parlamento brasileiro, Paulino José Soares de Sousa, visconde do Uruguai, ministro e secretário de Estado para Assuntos Estrangeiros do Império do Brasil, contestou veementemente a argumentação de M. F. Maury, que se valeu dos acordos do Tratado de Viena para pressionar a abertura do rio Amazonas aos navios norte-americanos:

\begin{abstract}
No Brasil, o Conselho de Estado, ao examinar, em $1^{\circ}$ de abril de 1854, a questão da abertura do rio Amazonas à navegação internacional, debruçouse sobre o Parecer da Seção dos Negócios Estrangeiros acerca do assunto, elaborado por Paulino Soares de Souza, Abrantes e Lopes Gama, no qual, referindo-se ao pactuado no Congresso de Viena, os relatores bem lembravam: "Estas disposições de mero direito convencional somente regulam e obrigam as Potências que nela convierem. Não foram admitidas pela Europa em geral, e menos por todo o mundo". E, mais adiante, pontificavam: "O que algumas Nações da Europa estipularam a respeito de alguns rios da Europa, que lhe pertenciam, não estabelece direito entre Nações da América sobre rios da América que lhes pertencem, sem que por atos seus adotem e dêem força àqueles princípios". (...) O princípio de soberania territorial, dentre os quais Kluber Martens, Wattel, Puffendos, Chilty e Wolff, para concluir que a soberania sobre rios internacionais não se cinge às suas nascentes, porém a todo o curso, e que as nações ribeirinhas têm propriedade sobre os trechos fluviais que atravessem seus respectivos territórios, podendo negar trânsito às demais, inclusive passagem aos ribeirinhos superiores. Por consequência, apenas o direito convencional estabeleceria servidão sobre o uso de suas águas a terceiros países. (PALM, 2009, p. 45-50)
\end{abstract}

Segundo Paulo Palm (2009), o Brasil se viu defrontado com um "dilemma moral": ao mesmo tempo em que mantinha uma política restritiva no Amazonas, tentava no Prata persuadir o Paraguai e vizinhos ao sul para abertura à navegação. Como já indicamos, nem todos os países conseguiram resolver tais impasses diplomaticamente (PALM, 2009). Veremos que o presidente Carlos Antonio López

\footnotetext{
${ }^{21}$ Wheaton enumera acordos livre navegação dos Estados Unidos com cada Estado sul-americano (principalmente, Confederação Argentina, Bolívia e Peru, Brasil e Paraguai), conforme parecer do diplomata John Randolph Clay, figura muito próxima aos sulistas no período e influente nas relações de persuasão em relação à região estudada (U.S. Laws X.123t., X.28t., Xii291t., Xii 117t., X.283t., X.199t).
}

Revista Eletrônica da ANPHLAC, ISSN 1679-1061, n.15, p. 79-112, jul./dez. 2013. http://revista.anphlac.org.br/ 
tentou defender a vigência, ou preponderância, da jurisprudência nacional sobre tratados comerciais, restringindo tráfego no rio Paraguay. Tal medida acabou por levar o seu país a um conflito com os Estados Unidos.

\title{
4. O Império do Brasil: limites de navegação a determinados trechos.
}

Como ao Império do Brasil interessavam "as estradas líquidas" para o Prata, liberou-se a navegação de Page, em trechos limítrofes, pois nem mesmo o Brasil tinha definido o direito de navegação continua no rio Paraguay. Trâmites viabilizaram a expedição dos norte-americanos, após trabalhosa persuasão do corpo consular em exercício na região. No excerto abaixo, Page (1871) expõe uma de suas metas principais: definir um tratado de livre navegação dos rios com o país.

\begin{abstract}
Além de realizar uma prospecção e explorar os rios da Prata e adjacentes, Presidente Sr. Fillmore confiou-me a incumbência de, junto aos nossos ministros [cônsules e embaixadores], seja em proximidade aos governos do Brasil e da Argentina ou individualmente, firmar um tratado com o Paraguai. (p.26)
\end{abstract}

Page esteve pessoalmente no Rio de Janeiro, pressionando para obter autorizações do Império. Em plena epidemia de febre amarela, o Water Witch foi liberado da quarentena para entrar no país. Precisava resolver, sobretudo, a navegação dos rios. Do rio Paraguay, conseguiu autorização para trechos com margem em território brasileiro. No relato, Page (1871) comenta o protecionismo sul-americano: “Corumbá se tornará importante mercado quando o Brasil abandonar a política de exclusividade à navegação dos rios e o Paraguai declarar abertura do rio a todas as bandeiras" $\left(\right.$ p.15) ${ }^{22}$.

Ciente dos termos de soberania, jurisdições nacionais e possíveis complicações, Page cuidadosamente notificou o trajeto, conforme realizado pelo território brasileiro, enumerando as visitas. Concessões das autoridades brasileiras geralmente eram dadas antes da viagem. No entanto, ele aponta que alguns detalhes foram decididos apressadamente. Segundo Page (1871), ele só recebeu autorização para a navegação do trecho do rio Paraguay até Corumbá, durante o curso da viagem:

Deve-se observar que esta recusa não era absoluta, mas a permissão foi dada ao Water Witch para subir o rio Paraguay até Albuquerque, com

\footnotetext{
${ }^{22} \mathrm{O}$ autor informa que "do Rio de Janeiro ao Mato Grosso por terra viajava-se geralmente 1.200 milhas (cerca de $1.930 \mathrm{~km}$ ) utilizando-se mulas de transporte" (p.161).
}

Revista Eletrônica da ANPHLAC, ISSN 1679-1061, n.15, p. 79-112, jul./dez. 2013. http://revista.anphlac.org.br/ 
alguma extensão, dentro do limite territorial reivindicado pelo Brasil. Ao chegarmos em Coimbra, no primeiro posto militar do Império no Paraguay, fui informado que nosso privilégio de subir o rio havia sido prorrogado até Corumbá, a 60 milhas acima de Albuquerque. (p.285)

Page buscou garantias diplomáticas, por intermédio do cônsul Robert Schenck e Ferdinand Coxe, seu substituto. Em correspondência, pediu assistência a José Paulino Soares de Souza, ministro de Relações Exteriores do Império e "sua amigável cooperação para alertar aos oficiais do Império e agentes que ele viesse a encontrar na trajetória de suas operações, ou extensões do poder da capital” (PAGE, 1856, p.5).

Sob ordens do Presidente dos Estados Unidos [Millard Fillmore], a missão do Water Witch pelo comandante Page de explorar e prospectar todos os rios da bacia do Prata, trará resultados da maior importância ao mundo comercial e científico. Estando o Brasil à margem dos rios necessários para ascendermos, não será menos beneficiado por essas operações. (...)Vossa Excelência sabe muito bem o que estas ordens deverão significar e a quem deverão ser delegadas. Estou apenas comunicando o requerimento feito pelo comandante Page ao Sr., afinal confio que sua visão ilustrada o levará a passar o pedido e objeto da expedição a todas extensões do poder de Vossa Excelência. (PAGE, 1856, p.5) (23 $^{23}$

Em resposta, Paulino pronunciou que o governo imperial estava aberto ao comércio estrangeiro no rio Paraguay e não faria objeções para que Page realizasse explorações, mas limitava-o ao porto de Albuquerque. Acrescentou que delegaria ao presidente da província de Mato Grosso e demais agentes que lhe oferecessem "toda a cooperação necessária” (PAGE, 1856). Advertiu-lhes, porém, que Page não ultrapassasse o ponto do acordo, ou abriria precedente prejudicial às relações do Brasil com o Paraguai, já que os direitos à navegação nesses rios não estavam bem definidos entre os vizinhos (PAGE, 1856, p.6-7) ${ }^{24}$.

\section{A Confederação Argentina apoia a livre navegação de Page pela região.}

Quando o Water Witch chegou à Argentina, em meados de 1853, o país estava dividido entre o grupo herdeiro dos unitários - liberais influenciados por ideias

\footnotetext{
${ }^{23}$ Requerimento feito por Robert Schenk, a quem Page respondia no esquema diplomático da América do Sul.

${ }^{24}$ Importa salientar que, mesmo na dimensão dos assuntos estratégicos, determinados aspectos secretos foram preservados à alta inteligência da U.S. Navy: "Os detalhes mais importantes envolvidos nestas questões [da navegação] não devem ser incluídos neste relatório" (PAGE, 1856, p.8). Já a questão sobre a navegação do Paraguay perdurou também regionalmente. Em 1851, o Brasil garantiu um tratado de navegação franca no rio Uruguay. Page (1871) menciona, no começo do relato, tentativas de Manuel Oribe, caudilho uruguaio e aliado de Rosas, de proibir a navegação, em 1856, nos rios Parana e Paraguay, em trechos que alegavam estar sob jurisdição de ambas as soberanias.
}

Revista Eletrônica da ANPHLAC, ISSN 1679-1061, n.15, p. 79-112, jul./dez. 2013. http://revista.anphlac.org.br/ 
europeias, que lutavam por um governo centralizado a partir da cidade de Buenos Aires - e o dos federalistas, que reunia líderes que lutaram e mantiveram uma confederação por algumas décadas, sustentando o poder das províncias sobre Buenos Aires. Exemplo máximo de federalista foi o caudilho Juan Manuel de Rosas. Enquanto governador da província de Buenos Aires, exerceu forte poder sobre demais províncias e a população, marcando indelevelmente o período da Confederação ${ }^{25}$.

Entretanto, em fevereiro de 1852, na Batalha de Caseros, as forças do Império do Brasil, liberais uruguaios, liberais argentinos e mais líderes federalistas de Entre Ríos e Corrientes - antirrosistas, descontentes com a concentração de poder em Rosas e o "fechamento" do Prata aos negócios das províncias - depuseram o caudilho, pondo fim a uma era da Confederação Argentina ${ }^{26}$.

A porta de entrada do Prata foi facilitada aos sulistas devido à ascensão política do caudilho Justo José de Urquiza, governador antirrosista de Entre Ríos, em uma conjuntura de grave disputa interna (TERNAVASIO, 2009). Urquiza era um líder provinciano federalista que tinha trânsito entre alguns unitários. Grande proprietário de terras e dono de navios, se destacava por retirar negócios importantes na indústria do charque; ele tinha ampla influência nas esferas elitistas locais como também abertura às negociações internacionais (MEDRANO, 1989).

Ao ser nomeado diretor provisório da Confederação Argentina, pelo Acordo de San Nicholás (1852), a primeira atitude de Urquiza foi liberar a navegação internacional dos rios (SCOBIE, 1964) ${ }^{27}$. No começo da narrativa, Page (1871) descreve a decisão:

Após a derrota e exílio de Rosas e a eleição de Urquiza como diretor provisório da Confederação Argentina, uma das primeiras medidas de sua administração foi impor um decreto, no dia 28 de agosto de 1852, declarando a livre navegação dos rios da Confederação a todas as bandeiras. Ele tomaria vigor no $1^{\circ}$ de outubro do mesmo ano. $\mathrm{O}$ pacto sobre a grande extensão de águas navegáveis estava rompido e oferecia

\footnotetext{
${ }^{25} \mathrm{O}$ caudilho não pode ser visto apenas como líder extremamente autoritário que domina a população ingênua. Sobre a relação entre esses líderes locais e os seus seguidores, ver: LA FUENTE (2005).

26 "Entre 1838-1840, a Confederação sofreu um bloqueio naval imposto pela França, que ocupou o porto de Buenos Aires e a entrada do rio da Prata. Com apoio do Uruguai, a França objetivava derrubar Rosas e obter maior influência econômica e política na região. Com habilidade, Rosas negociou a suspensão do bloqueio, fortalecendo-se politicamente. Em 1845, proibiu o acesso de navios estrangeiros aos rios Uruguai e Parana. A resposta externa não tardou. França e Inglaterra impuseram um segundo bloqueio aos portos da Confederação. O governo de Buenos Aires conseguiu sua suspensão definitiva em 1850" (BEIRED, 1996, p.25).

${ }^{27} \mathrm{O}$ acordo pretendia formar um governo constitucional. Contudo, enquanto não promulgassem uma constituição, o governo provisório, na pessoa do diretor provisional da Confederação Argentina (Justo José de Urquiza) reuniria os poderes legislativo e executivo.
}

Revista Eletrônica da ANPHLAC, ISSN 1679-1061, n.15, p. 79-112, jul./dez. 2013. http://revista.anphlac.org.br/ 
comunicação com o Atlântico a uma nação que abarcava nada menos que 8.800 .000 milhas quadradas. Abriu-se um vasto território, não somente ao comércio, como as facilidades mais liberais concedidas à imigração. Os resultados, visíveis logo neste período, demonstravam a sagacidade de Urquiza e antecipavam a prosperidade que aquela porção da América do Sul viria a adquirir sob sua ilustrada administração. (p.25)

Todavia, conflitos entre unitários e federalistas provocaram disputas políticas até a metade do ano seguinte, 1853, um momento extremo quando Buenos Aires encontrou-se sitiada por terra e bloqueada pelo rio ${ }^{28}$. Grande parte dos unitários não admitia um caudilho como presidente da Confederação. Como explica o historiador James Scobie (1964), em A luta pela consolidação da nacionalidade argentina (18521862), "Se em fevereiro de 1852 Urquiza havia entrado triunfalmente na cidade de Buenos Aires, no dia 13 de junho de 1853 ele abandonava a cidade sob a escolta dos representantes diplomáticos estrangeiros" (p.95) ${ }^{29}$.

Sobre a região em conflito, Page (1871) relata:

Os capítulos históricos que acompanham esta narrativa apresentarão um relato detalhado dos assuntos políticos aos países adjacentes ao rio da Prata. Atualmente, é apenas necessário colocar a premissa que no movimento contra Oribe, Urquiza e o imperador do Brasil tinham em vista um grande objeto: a abertura das comunicações de La Plata ao comércio. (...) $\mathrm{O}$ governo dos Estados Unidos foi o primeiro a se aproveitar desta oportunidade oferecida a todas as nações marítimas para obter-se amplo conhecimento da região. Designaram uma expedição para explorar seus rios, informar extensões de navegabilidade e adaptação comercial. Ela foi colocada sob meu comando em fevereiro de 1853. Assim que cheguei na Argentina, fui convidado pelo cônsul britânico Sr. Charles Hotham, por meio do Sr. Pendleton [o cônsul norte-americano] a acompanhá-lo ao Paraguai, junto aos Ministros da França e Sardenha, que haviam acabado de concluir um tratado com aquele país. (p.25)

Page justifica a movimentação dos aliados locais para conter Manuel Oribe, com objetivo de proteger o livre comércio na região. Entende-se que o comandante, a rede consular norte-americana em exercício na região e demais representantes diplomáticos internacionais haviam preparado terreno para acordos entre Brasil e Argentina, autorizando a expedição da U.S. Navy, em áreas sob essas jurisdições ${ }^{30}$.

\footnotetext{
${ }^{28}$ Ainda que o país estivesse dividido, Buenos Aires recebeu mais navios oceânicos. Tecnicamente, oferecia vantagens para descarregar, distribuir e comerciais. Pelo peso das embarcações e a profundidade do porto, Rosário não oferecia segurança (KROEBER, 1967, p.76).

${ }^{29}$ Desde 1853, ano em que fora promulgada a Constituição Argentina e também quando delegou-se a Urquiza o posto de diretor provisional, a região passou por nova divisão: a província de Buenos Aires declarara a secessão da Confederação, que agora tinha como capital Rosário e passou a ser chamada de Estado de Buenos Aires. Como mencionado, apesar das alianças que permitiram a derrocada de Rosas, Buenos Aires recusara-se a se submeter novamente a um federalista.

${ }^{30}$ Em correspondência à Secretaria da U.S. Navy, R. Schenk, cônsul dos EUA no Brasil, comenta sobre a constituição de Santa Fé "é quase idêntica à nossa". Submetida às províncias para aprovação, fora
}

Revista Eletrônica da ANPHLAC, ISSN 1679-1061, n.15, p. 79-112, jul./dez. 2013. http://revista.anphlac.org.br/ 
Enquanto isso, por meio de alianças com potências navais - Grã-Bretanha, França, Sardenha e Estados Unidos - promoveu-se tratado concedendo a livre navegação do Prata e adjacentes aos signatários. Abaixo, inclui-se um excerto do tratado:

\begin{abstract}
O presidente dos Estados Unidos e Sua Excelência, o diretor provisório da Confederação Argentina, desejando fortalecer os laços de amizade que tão alegremente subsistem entre seus respectivos Estados e países, e convencidos de que o meio mais seguro para se chegar neste resultado é tomar-se coletivamente todas as medidas necessárias para facilitar e desenvolver relações comerciais, resolveram determinar por um tratado as condições da livre navegação dos rios Parana e Uruguay, eliminando-se os obstáculos que até agora impediram sua navegação. (FLORES, 1853 apud MALLOY, 1910, p.12)
\end{abstract}

Opositores de Urquiza retomaram as instituições de Buenos Aires, expulsando os representantes da Confederação, como já indicado. Aconselhado por John Pendleton, cônsul norte-americano em Buenos Aires, Page arcou com a transferência do agora ex-presidente da Confederação, levando Urquiza, entre outros, no Water Witch, de Buenos Aires até o porto vizinho de Gualeguaychu (seguia para Entre Ríos). Em relatório direto ao secretário da Marinha, Page reclamava que não esperava ter que escoltar Urquiza, apoiadores e cidadãos norte-americanos dali de Buenos Aires:

\begin{abstract}
A rapidez com que Urquiza emitiu sua ordem me causou um insight sobre sua maneira ágil e decisiva para tramitar negócios. No retorno à cidade, embora nenhum contratempo pudesse ser esperado, como ato de cortesia, ele ordenou uma escolta, comandada por um de seus oficiais favoritos, para acompanhar-nos à frente dos focos do exército sitiante. (...) Eu não esperava qualquer detenção em Buenos Aires além do tempo necessário para análise e aquisição de papéis e documentos que eu considerasse importantes para facilitar nosso avanço na exploração de rios sobre quais, em diferentes pontos, nações vizinhas - Brasil, Confederação Argentina, Paraguai, Bolívia e Uruguai - alegavam jurisdição. (PAGE, 1871, p.18)
\end{abstract}

Segundo o comandante, o incidente atrasou o curso da viagem. Contudo, ele assumiu que valeu pela troca de favores, alinhando interesses norte-americanos aos da Confederação Argentina. Todavia, mesmo que o senso de oportunidade tenha definindo o trânsito do Water Witch pela região, foi por meio de trabalhosos esforços diplomáticos que conseguiriam garantir acordos na região.

recebida com entusiasmo, exceto por Buenos Aires. Segundo Schenk (PAGE, 1871, p.569-570), disputas internas e incertezas sobre a legitimidade do acordo da navegação argentina abalaram a cooperação entre signatários, Estados Unidos Grã-Bretanha e França, deixando-os aos próprios interesses e em competição (PAGE, 1871, p.575-579).

Revista Eletrônica da ANPHLAC, ISSN 1679-1061, n.15, p. 79-112, jul./dez. 2013. http://revista.anphlac.org.br/ 


\title{
6. Paraguai: limites à navegação internacional.
}

Edward Hopkins, ex-oficial da U.S. Navy, foi o primeiro a persuadir o então secretário de Estado norte-americano, James Buchanan, sobre o "futuro promissor" do Paraguai. Em uma carta a Buchanan, ele certificou; "É o Estado mais forte e rico do Novo Mundo, depois dos Estados Unidos” (FITZGERALD, 1973). Então, forjou relações consulares, convencendo o presidente James Polk a realizar uma expedição ao país, em 1845 (MEDRANO, 1989) ${ }^{31}$.

Logo Hopkins aproximou-se do presidente Carlos Antonio López. Eles negociaram o reconhecimento da independência paraguaia pelos EUA - e pela Confederação Argentina - em contrapartida de um Tratado de Comércio e Navegação, aponta o historiador norte-americano Oscar Fitzgerald (1973). O acordo de 1853 garantiu o monopólio de quinze anos sobre a exploração dos transportes a vapor e indústrias de tijolo, placas de madeira, tabaco, e têxtil à The United States and Paraguay Navigation Company, companhia fundada em 1852, com capital inicial de U\$100,000,00, dentre investidores norte-americanos e internacionais (FITZGERALD, 1973). O historiador Clifton Kroeber (1967) analisou a presença de Hopkins no país:

\begin{abstract}
Hopkins foi o primeiro estrangeiro a explorar as possibilidades comerciais da navegação a vapor na bacia do Prata. Este jovem exaltado havia estado na Argentina e Paraguai em tempos de Rosas e regressou na década de 1850, para organizar serviços de vapores no Paraguai. Mas, como em setembro de 1854 foi expulso com seus maquinistas do país, transferiu suas operações à Argentina. Enquanto companhias argentinas e britânicas montavam serviços regulares de vapores no rio Parana, alguns governos estrangeiros enviaram várias expedições para explorar os rios e confeccionar mapas a fim de oferecer maior segurança à navegação a vapor nos rios Parana e Uruguay, assim como para investigar as possibilidades de comércio nesta parte quase desconhecida do mundo. (p.94)
\end{abstract}

Com penetração no Paraguai e em Washington, Hopkins viabilizou a expedição de Page ao Prata, envolvendo o secretário da Marinha J.P. Kennedy na American Geografical and Statistical Society. Ele foi nomeado cônsul e ministro especial do Paraguai nos Estados Unidos e, entre outras frentes, da American Company, além de ter fundado uma fábrica de cigarros, em 1853. Contudo, em 1854,

\footnotetext{
${ }^{31}$ Segundo a historiadora, "a construção naval e siderurgia paraguaias ganharam impulso com a supervisão de técnicos estrangeiros, especialmente convidados pelo governo" (p.20). O Paraguai isolou-se de conflitos platinos pós-independência, e Francia manteve o controle da vida econômica (produção, circulação e distribuição). López deu continuidade, embora buscando inserir-se na política regional com iniciativas de comércio exterior, mantendo monopólio estatal junto a empresas privadas. A Confederação Argentina (J.J. Urquiza) reconheceu a independência do país, em 1852.
}

Revista Eletrônica da ANPHLAC, ISSN 1679-1061, n.15, p. 79-112, jul./dez. 2013. http://revista.anphlac.org.br/ 
essa aliança começou a decair. López acusou Hopkins de sonegar impostos de exportação e, coincidência ou não, no mesmo ano, Solano López, seu filho e vicepresidente, começou a produzir cigarros. Desacordos que incidiram em um caso de agressão física a parentes de Hopkins e irregularidades sobre a posse de terras resultaram no fechamento da fábrica e demais desentendimentos (FITZGERALD, 1973, p.72).

Sabe-se que o governo do Paraguai incrementou a marinha nacional, investindo em navios a vapor, na década de 1850, visando a assegurar sua legitimidade, independência e também fortalecer sua economia. Clifton Kroeber (1967) explica como se excluíram os norte-americanos da indústria naval do país ${ }^{32}$.

\begin{abstract}
Os recursos do Paraguai eram limitados, mas López alocou dinheiro para comprar motores e acessórios para barcos a vapor, contratar estrangeiros, equipar, construir oficinas de reparação e material. John K. Whitehead, engenheiro altamente capacitado, foi encarregado da direção de todos esses projetos técnicos, no qual trabalharam muitos ingleses e demais estrangeiros. Equipes e principais postos nos vapores paraguaios eram formadas por ingleses e escoceses. Antes de sair da Inglaterra, em 1854, Whitehead havia comprado um determinado número de motores. Ele permaneceu por dez anos pelo Paraguai, construindo píeres, oficinas, fábricas e galpões. Também o governo paraguaio havia enviado alguns jovens à Inglaterra para aprender navegação e engenharia a vapor. $\mathrm{O}$ programa, até 1860 , produziu dezenas de barcos, porém, toda essa obra foi destruída na Guerra do Paraguai (1865-70). (KROEBER, 1967, p.95)
\end{abstract}

Nota-se que, em certo momento, López substituiu a parceria com Hopkins por uma outra, com o inglês John Whitehead ${ }^{34}$. À época, Page cartografava a região, preparando-se para se dirigir à Bolívia. Porém, ao romper com Hopkins, López não só suspendeu o Tratado de 1853, que garantia seus interesses, como promulgou um Ato de Expulsão dos Estrangeiros, em 1854, eliminando tal presença no país. Embora Page acusasse essa proibição de ser contra os Estados Unidos, o Ato de 1854 impedia o trânsito de qualquer estrangeiro - cidadão ou navio -, de norte-americanos inclusive. Provavelmente, eles liberavam a quem os interessasse.

Apesar das negativas paraguaias, Page não perdia a oportunidade de valorizar

\footnotetext{
${ }^{32}$ No século XIX, Argentina e Uruguai pouco investiram na indústria naval; quando sim, pela iniciativa privada e com material importado. Já no Paraguai, por muito tempo, embarcações nacionais superaram as estrangeiras (KROEBER, 1967).

33 Assunción manteve comunicações rápidas com outros portos; Corumbá e Cuiabá, Parana (Argentina), Rosário, Buenos Aires e Montevidéu. Itinerários combinavam linhas ultramarinas francesas, a viagem até Buenos Aires diminuiu de vinte para sete dias (KROEBER, 1967).

${ }^{34}$ Solano López era frequentador da corte francesa (Napoleão III) e ambientes da elite britânica. Ele liderou uma série de expedições à Europa, entre 1853 a 1856, na companhia de seu pai e de John Whitehead. Utilizavam navios produzidos no Paraguai.
}

Revista Eletrônica da ANPHLAC, ISSN 1679-1061, n.15, p. 79-112, jul./dez. 2013. http://revista.anphlac.org.br/ 
os feitos norte-americanos. Ele comentava a presença britânica na indústria naval do Paraguai, fazendo propaganda da especialidade aprimorada nos Estados Unidos, a construção de barcos específicos à navegação de rios:

\begin{abstract}
Tendo fé em evidências de que à ascensão do rio Vermelho seja navegável por navios a vapor, formou-se uma companhia composta por alguns ingleses empreendedores, com este fim. Eles receberam privilégios exclusivos do governo da Confederação Argentina e adquiriram quatro pequenos vapores na Inglaterra. Dividindo profundo interesse a todos os empreendimentos, frutos do nosso trabalho, aconselhei-os que vapores necessários à navegação, em especial dos pequenos afluentes dos rios centrais, devessem vir dos Estados Unidos. Pois, fora de qualquer sentimento nacional e sem refletir sobre a habilidade de ingleses na construção de navios, eu não hesito em afirmar que, em nenhuma parte do mundo, se tenha a construção de barcos de pequeno calado à mesma medida, ou se levado à perfeição, como nos Estados Unidos, pela simples razão de que aqui nós temos uma navegação de extensão interior valiosa, a engenhosidade de designers para concebê-los, aplicando meios de propulsão que os capacita a admitir as menores baixas de rio possíveis. (PAGE, 1871, p.444) ${ }^{35}$
\end{abstract}

A desavença entre os sulistas norte-americanos e o governo paraguaio rendeu ameaças que, em pouco tempo, culminaram no ataque ao Water Witch, em 1855, consequente ao não cumprimento da expulsão de todos os estrangeiros - e norteamericanos - do Paraguai ${ }^{36}$.

\title{
7. Interesses norte-americanos em outras partes da América do Sul.
}

Ante a desavença com López, frustraram-se interesses que relacionavam a viagem de Page aos demais países sul-americanos, para além do Prata. Pretendia-se afirmar uma logística continental, com saída do Atlântico ao Pacífico, pelo Prata (Paraguai e Argentina), e do Pacífico ao Atlântico, pelo Amazonas (do Peru ao Pará, assim como percorreram os viajantes W. Herndon e L. Gibbon, em 1851). A missão de Page estava focada na saída para o Pacífico, por isso, ele precisava ultrapassar o Grande Chaco - pela Argentina ou pelo Paraguai. Os sulistas se articularam às elites na Bolívia e no Peru visando, especialmente, à exploração de minérios; no Chile, à

\footnotetext{
${ }^{35} \mathrm{O}$ autor indica estar escrevendo dos Estados Unidos.

${ }^{36}$ Após desacordo entre López e Hopkins no Paraguai, em 1854, a Secretaria de Estado dos EUA enviou o representante R. C. Buckalew, para renegociação do acordo ratificado em 1853, por J. Pendleton, Chargé d'Affaires em Buenos Aires. Sem sucesso, enviaram Richard Fitzpatrick no mesmo ano. Ele retornou em 1856, ainda sem nada resolver. Isso impulsionou a mobilização do Congresso pelo presidente J. Buchanan à intervenção da U.S. Navy, em 1858. A restituição do acordo (1853) teve a intermediação de J.J. de Urquiza.
}

Revista Eletrônica da ANPHLAC, ISSN 1679-1061, n.15, p. 79-112, jul./dez. 2013. http://revista.anphlac.org.br/ 
exploração do guano ${ }^{37}$. Também estiveram presentes no Equador, Colômbia e Venezuela, abordando diversos interesses ${ }^{38}$.

No início da narrativa de viagem, Page comentou o encontro com Wenceslao Paunero, o "cunhado de Ballivián” (Jose Ballivián Segurola, presidente da Bolívia entre 1841 e 1847). Naquele momento, Paunero estava em serviço do Departamento de Guerra, em Montevidéu, após ter liderado a Batalha de Caseiros (1852), responsável pela queda do governo de Rosas, como já indicado. Posteriormente, foi general da Tríplice Aliança, em 1865, contra o Paraguai de Solano López ${ }^{39}$.

Antes de partir de Montevidéu, procurei o Coronel Wincheslao Paunero [Sic.], um oficial do Departamento de Guerra, cunhado do falecido presidente Bolivian [Ballivián] da Bolívia. Muito generosamente, obtive dele o empréstimo de um mapa muito bem executado, a partir do qual eu pude planejar; parecia ser autêntico, realizado em data mais recente do que qualquer outro que eu havia visto. O mapa foi executado sob a administração do General Bolivian [Sic]. Coronel Paunero comentou que teria muito prazer em oferecê-lo a mim, em benefício da expedição; e como foi deixado a ele um legado do amigo e parente, fez isso com muita cortesia. Ele parecia bem interessado no nosso trabalho, mandou por mim uma carta de apresentação ao Chargé [d'Affaires] boliviano em Buenos Aires, Sr. D. Juan de La Cruz Bennavento, a quem eu encontrei entusiasmado com o assunto da nossa expedição, na esperança de que ela poderia ser um meio de estabelecer a vitalidade ou alguma saída para os produtos de seu isolado país, pelas águas de La Plata. (PAGE, 1871, p.3)

O trecho acima foi um divisor de águas para a nossa investigação sobre os objetivos implícitos de Page, porque comprova a sincronia de sua viagem com a de William Herndon à Amazônia, em 1851. Ballivián e o mapa produzido em expedição ao rio Pilcomayo, durante seu governo, aparecem nos dois relatos, revelando continuidades e incumbências relacionadas aos sulistas na região. Eles esperavam que o Pilcomayo abrisse a passagem do Prata ao Amazonas (HERNDON, 1854) ${ }^{40}$.

\footnotetext{
${ }^{37}$ Mineral abundante nas cercanias do deserto do Atacama, utilizado como fertilizante, tornou-se altamente valorizado nas bolsas de valores do mundo. A atividade gerou desentendimentos entre a Bolívia e o Chile, poucas décadas depois, em 1872, resultando na perda das saídas da Bolívia para o mar, na Guerra do Pacífico (1879-1883).

${ }^{38}$ De forma similar, Bolívia, Equador e Peru declararam livre navegação dos rios, em 1853.

${ }^{39}$ Após a Guerra do Paraguai, Paunero aposentou-se no Rio de Janeiro.

${ }^{40} \mathrm{Na}$ abertura do relato, Herndon (1854) cita informações privilegiadas; rotas para navegação a vapor pelos Andes, notificando minas de ouro, prata, estanho etc. Tradução da autora: "O comandante das Forças Navais Britânicas no Pacífico, Almirante Hornby, interessado em minha missão, dividiu informações, assim como George Hobson II, V War George Coog e o Comodoro Simpson, da marinha chilena, que me emprestou livros de sua vasta biblioteca e mapas, ajudando na formulação dos meus planos. O sr. Bridges, florista e botânico britânico, fez uma descrição das águas mais aptas à navegação nas nascentes das correntes, para que eu passasse ao sr. Gibbon. Também estive com o General Ballivián, ex-presidente da Bolívia, em exílio no Chile. Ele me emprestou um mapa da Bolívia que foi feito sob suas ordens, enquanto presidente da República. Mas eu, que o tinha tomado em mãos, tive o infortúnio de perdê-lo" (PAGE, 1871, p. 34, grifo meu).
}

Revista Eletrônica da ANPHLAC, ISSN 1679-1061, n.15, p. 79-112, jul./dez. 2013. http://revista.anphlac.org.br/ 
Na publicação Bosquejo Estadístico de Bolívia (1851), o jurista José Maria Dalence, apresenta os privilégios garantidos diplomaticamente aos norte-americanos. Também pontua os desentendimentos circunstanciais entre Bolívia, Paraguai e "Dom Pedro e os Portuguezes" (p.132), acerca das fronteiras territoriais de Otuquis, no Chaco - conflitos considerados o "germe" da Guerra do Paraguai ${ }^{41}$. Dalence (1851) anunciava incentivos como um prêmio de dez mil dólares, além de terras públicas, a quem comprovasse a navegabilidade a vapor no Pilcomayo, ou "custeasse obras da engenharia contemporânea, com dragas de construção portuária” (p.132). Embora muito publicadas em jornais norte-americanos, Page não comenta tais informações no seu relato.

\section{A contenda diplomática entre Page e López pela navegação do rio Paraguay.}

Mesmo com um Decreto (de outubro de 1854), proibindo qualquer navio de guerra estrangeiro em território paraguaio - e expulsando qualquer cidadão norteamericano -, a expedição permaneceu. Assim, em 1855, na ausência de Page e da "melhor parte dos oficiais", em frente ao Forte Itapiru, o "Gibraltar Paraguaio", iniciou-se a contenda que culminaria em "graves consequências" para o Paraguai.

Segundo Page (1871) descreve, o Water Witch, estava a duzentas milhas da margem argentina do Parana, quando parou, "devido a um banco de areia" (p.246). Em um pequeno barco, oficiais paraguaios entregaram a notificação do chefe do Forte Itapiru, reforçando estar proibida a navegação ali. Da proa do navio, o tenente William Jeffers alegou não compreender os termos da carta, uma vez que não dominava o espanhol. Logo, oficiais paraguaios dispararam três tiros de festim. Jeffers contra-atacou, sem conseguir atingi-los. Na sequência, paraguaios responderam com dez tiros, avariando o Water Witch. O episódio matou o timoneiro (helmsman) Samuel Chaney ${ }^{42}$.

Entretanto, não há certeza sobre a ordem dos fatos e se o navio estava mesmo ancorado. Quando escreveu essa parte da narrativa, Page já estava nos Estados Unidos, com o trabalho que deveria fazer no Prata inacabado, defendendo uma punição dos Estados Unidos contra o Paraguai, em razão das avarias feitas no Water Witch (FITZGERALD, 1973). Indignado, Page (1871) comentou o hostil “insulto":

\footnotetext{
${ }^{41}$ Dalence (1851) define o lago Oberaba como sendo o "Tibete da América"; sabe-se que essa região é responsável por abastecer a hidrografia da China.

${ }^{42}$ Mais tarde, Page inverteu a situação, alegando que o paraguaio não compreendia o inglês.
}

Revista Eletrônica da ANPHLAC, ISSN 1679-1061, n.15, p. 79-112, jul./dez. 2013. http://revista.anphlac.org.br/ 
Para que essa indignação apareça em sua verdadeira luz, deve-se considerar que o decreto de 3 de outubro, de 1854 não poderia incluir as águas em que o Water Witch estava quando se disparou contra ele. $\mathrm{Na}$ verdade, nenhuma parte do rio Parana está sob jurisdição exclusiva do Paraguai. Até no Forte Itapiru, duzentos quilômetros à frente no rio, fronteiras são comuns à Confederação Argentina (Corrientes) e Paraguai. O insulto em si mesmo é um fato que não pode ser tolerado; no entanto, é ofuscado pela fraude que o presidente López tenta impor ao público pelas colunas do [jornal] Seminário. Sobretudo, inclui-se aqui um esboço cartográfico do nosso posicionamento no rio, do forte e arredores, representando os tiros disparados em defesa do Water Witch, depois que seu timoneiro foi morto em uma atitude hostil. Requer-se perspicácia para que oficiais responsáveis sejam "severamente punidos". (p.308) ${ }^{43}$

Portanto, de acordo com o autor, o Paraguai não tinha razões para o que fez; sobretudo, contra "uma expedição sob ordens do governo norte-americano" (p.448). Para ele, o presidente López (que era especialista em jurisdições) agiu em desacordo com a Lei das Nações, "Fez má interpretação do direito internacional acerca dos direitos sobre a fronteira, pela qual defendia jurisdição sobre o canal” (p.448). Além de negar que o Water Witch violava um direito nacional, ele insinuou que, ao provocar a contenda, López estaria "chamando-o para uma guerra de papel" (p.446), ou seja, declarada.

Evidentemente, o presidente do Paraguai precavia-se à antecipação de uma retaliação minha pelo insulto e trovejou contra o Water Witch. Seus artigos pretendem impor credulidade aos paraguaios, mas devem excitar divertimento em La Plata. Ataques pessoais são feitos a mim pelos editoriais do seu pequeno veículo semanal El Seminário; desde a remoção dos americanos, eu não havia percebido que Vossa Excelência me chamava para uma guerra de papel. Mas o povo despertará consciência para a gravidade deste ato totalmente em desacordo com a Lei das Nações. Ele se justifica ousadamente, alegando jurisdição ao longo do canal principal do Parana, como se o navio corresse perto de suas margens [Paraguai]. Quando ele se esforçou para fazer parecer que o Water Witch havia entrado em território paraguaio, violando um direito nacional, eu resolvi expor essa evasão - ou má interpretação a todos os princípios do direito internacional - em um dos principais jornais de Buenos Aires, declarei a posição do navio quando alvejado. Estava totalmente amparado pela Lei das Nações. Da minha parte, pretendi demonstrar como direitos sob a fronteira deverão ser reconhecidos plenamente [internacionalmente]. Não há justificativa em dizer que tiros de festim foram disparados, e uma mensagem entregue pelo Forte, pois não se reconhece o direito de o Paraguai controlar o rio. A proibição do presidente López foi um insustentável posicionamento de poder, e a execução dos tiros, em todos os sentidos possíveis, uma afronta agressiva. (PAGE, 1871, p.316)

Mesmo que os paraguaios tenham avisado aos norte-americanos por tiros (de

\footnotetext{
${ }^{43} \mathrm{Na}$ época, Page aproveitou para adiantar o seu relato de viagem.

Revista Eletrônica da ANPHLAC, ISSN 1679-1061, n.15, p. 79-112, jul./dez. 2013. http://revista.anphlac.org.br/
} 
festim) e por correspondência, Page não reconhecia os direitos do Paraguai em controlar a navegação do rio, julgando ilegítima a atitude do presidente. Ao se defender contra "acusações" de López em jornais locais, Page exprimia a convicção da superioridade cultural e política norte-americana, apontando a posição protecionista e pouco esclarecida - comprovação do "atraso" - do Estado sulamericano, em desacordo com os tratados internacionais.

Page (1871) também menciona os acordos positivos com o Brasil, descrevendo a situação, como se não estivesse interessado em explorar especificamente nada no Paraguai, apenas transitar pelo rio, em nome de resultados para o comércio e a ciência. Nota-se que ele precisava justificar uma possível intervenção dos Estados Unidos no Paraguai, para punir a afronta que não deveria ser tolerada $^{44}$.

$\mathrm{Na}$ controvérsia sobre a exata posição do Water Witch no incidente, Page (1871) defendeu a ilegitimidade do mapa apresentado por López. Ele afirmou que proporções errôneas foram ditadas ao "dócil desenhista" estrangeiro. Ele denunciou a incompetência do agente paraguaio, que "pode até ser hábil em dirigir tiros, mas pouco sabe sobre levantamentos hidrográficos" (p.312), novamente em tentativa de desqualificar os paraguaios:

\begin{abstract}
$\mathrm{Na}$ página ao lado, a cópia reduzida do esboço feito por ordem do Presidente López e um esboço verdadeiro do rio Parana, próximo à foz do Paraguay, a partir do gráfico do Water Witch. O "croqui" aqui oferecido é, sem dúvida, trabalho de um estrangeiro, porque não há, presumidamente, um nativo [paraguaio] capaz de fazê-lo, seja a partir de uma pesquisa ou mesmo ditado. Provavelmente, estes direcionamentos são do oficial de artilharia do Itapiru, que pode até ser hábil em dirigir tiros, mas pouco sabe sobre levantamentos hidrográficos. $\mathrm{O}$ presidente não se importa nem mesmo em representar a natureza no trabalho, pois pretendia ilustrar uma ideia. De seu escritório, longe da cena, ditou para o dócil desenhista um rio sinuoso, induzindo-o a inserir certos bancos de areia, e os representantes paraguaios afirmam a "ideia" de que pretendem apresentar para os Estados Unidos. Mas, Vossa Excelência, embora seja admirável diplomata, como o seu relator, infelizmente, é muito ignorante nos princípios mais básicos da hidrografia. (p.312)
\end{abstract}

\footnotetext{
${ }^{44}$ Em correspondência, Page (1871) explica-se ao Secretário da U.S. Navy (J.C. Dobbin), em 1855, afirmando que o Water Witch localizava-se a "pouco menos" de 200 milhas do Forte, contradizendo a Lei das Nações. Ele inclui o relato do tenente W.N. Jeffers, comandante do navio na sua ausência, que, conforme suas instruções, rumou à entrada do Paraguay. Na abordagem oficial, relatou não conseguir ancorar. S. Chaney morreu com os primeiros tiros da Guardia Cerrito. Jeffers tentou corresponder, mas a imensa armada paraguaia estava posicionada, aguardando "os brasileiros" (ação mencionada por Page). Ele afirma que eram cerca de 6.000 paraguaios contra apenas 28 no Water Witch.
}

Revista Eletrônica da ANPHLAC, ISSN 1679-1061, n.15, p. 79-112, jul./dez. 2013. http://revista.anphlac.org.br/ 


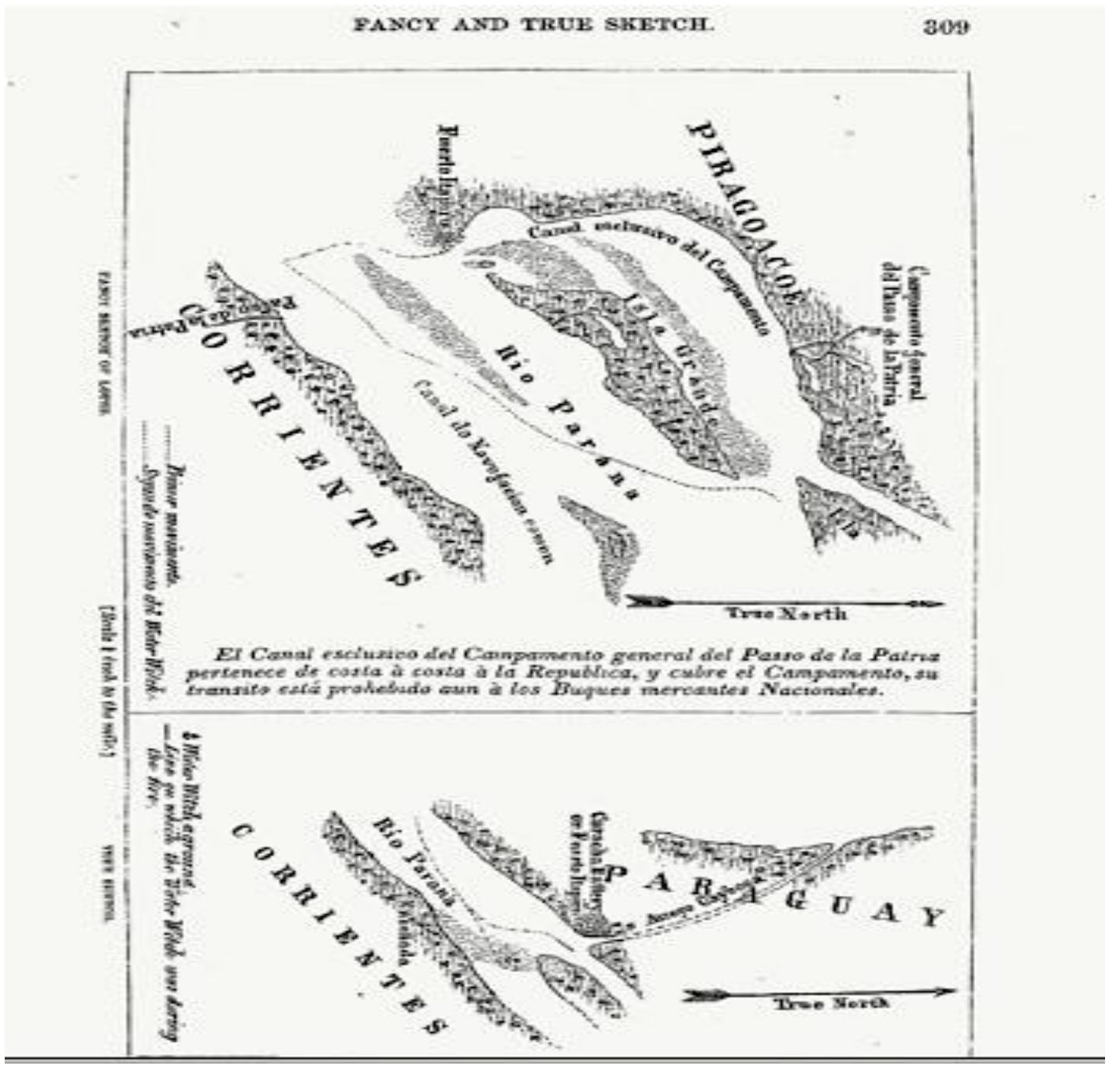

Croqui da região na qual o Water Witch foi atacado. Norte-americanos alegaram domínio da Confederação Argentina; logo, a Lei das Nações garantiria a livre navegação naquelas águas. (PAGE, 1871, p.309)

Page pediu apoio às autoridades brasileiras, mas, embora o Brasil tenha enviado simultaneamente uma comitiva que, em 1855, pudesse mediar as dissenções, seus aliados não corresponderam às expectativas imediatas. No relato, Page (1871) insinua os interesses brasileiros em questão, desdenhando das relações regionais. Afinal, como mencionado anteriormente, alguns pontos acerca da navegação dos rios na região, principalmente o Paraguay, vinham sendo definidos entre vizinhos. Mas autor provocava a discórdia ao afirmar, "Ao tratado que tanto se esperava, despeja-se a nulidade" (p.443). Assim, ele dava a entender que havia um fechamento generalizado das relações do Paraguai na região, possivelmente colocando o Brasil contra o país. De fato, nos anos seguintes, o Paraguai começou a se fechar, e a aliança entre Brasil, Uruguai e Argentina logo culminariam na Guerra do Paraguai ${ }^{45}$.

\footnotetext{
${ }^{45}$ Observa-se que o estopim da Guerra do Paraguai diz respeito à navegação do Paraguay. Em 1864,
}

Revista Eletrônica da ANPHLAC, ISSN 1679-1061, n.15, p. 79-112, jul./dez. 2013. http://revista.anphlac.org.br/ 
Um tratado foi concluído, concedendo ao Brasil o direito de navegação, da entrada do Paraguay a toda parte, reservando ainda alguns ajustes quanto à questão dos limites. Os documentos imperiais eram completos nesse tratado; honrarias foram derramadas sobre uma diplomacia bem-sucedida, um esforço de anos contra Rosas e López foi encerrado. O Brasil teve acesso por água ao noroeste de suas províncias, e navios bem abastecidos foram despachados para Cuiabá. Mas o que ocorreu ao final de tudo? Cada obstáculo inimaginável é jogado no caminho pelo governo do Paraguai. Os navios são parados desnecessariamente em guardas e cidades; passaportes vistoriados e reexaminados por todos e cada um; pilotos e cargas são alterados, o que envolve não somente o atraso da expedição, mas aumento de despesas. Ao tratado que tanto se esperava, despeja-se a nulidade. $\mathrm{O}$ Brasil enviou um embaixador para Assunción, com instruções especiais para remover todas essas dificuldades. Qual foi o resultado? Ele retornou, sem nada ter efetuado. Com certos preparativos bélicos, o Brasil enviou, em seguida, um ministro ao Paraguai, chegando a um acordo com o governo. (PAGE, 1871, p. 448)

Entretanto, sem o apoio de alianças políticas locais para retaliação imediata ao ataque, sem nada conseguir mudar, sem acordo, desapontado com o andamento do caso e incapaz de assumir qualquer responsabilidade sobre o incidente, Page foi constrangido a voltar para os Estados Unidos. Abaixo, a intimação de James Dobbin secretário da Marinha, em 1855, para que retornasse ao país:

SIR, - O Departamento está satisfeito com a energia exibida por você nos esforços para realizar as explorações e pesquisas para o qual foram enviados, em meio a muitas dificuldades. Minha opinião é que os interesses públicos exigem o retorno da expedição. Você deverá, portanto, assim que receber esta mensagem, dar sequência ao retorno do Water Witch aos Estados Unidos, para o porto de Washington. (PAGE, 1871, p. 480)

Sobre o retorno, e tendo um longo trabalho por terminar, Page comentou:

Quando nos lembramos das mudanças sociais e políticas transcorridas em apenas um ano, pode-se imaginar ansiedades e medos, esperanças e felicidades que movem o coração do marinheiro. E depois de uma expedição de mais de três anos em águas estrangeiras, finalmente se ouve o chamar do contramestre; "Todos a postos, subam a âncora, voltaremos para casa!" (PAGE, 1871, p. 480)

Enraivecido, Page culpava obviamente o governo paraguaio pelo mal-sucedido na expedição. Nos Estados Unidos, preparou o seu retorno à América do Sul, reunindo dados e fatos para uma argumentação convincente, capaz de garantir uma intervenção da força naval norte-americana ao Paraguai. Nos Estados Unidos, como

após a intervenção brasileira no Uruguai, aprisionaram o navio Marquês de Olinda com o presidente da província do Mato Grosso. Pelo Tratado de Paz de 1872, o Brasil garantiu a navegação contínua, assim como as fronteiras territoriais reivindicadas antes da guerra.

Revista Eletrônica da ANPHLAC, ISSN 1679-1061, n.15, p. 79-112, jul./dez. 2013. http://revista.anphlac.org.br/ 
mencionado, trabalhou mapas e se ocupou de finalizar a primeira parte da narrativa, sempre justificando suas ações e desqualificando as dos paraguaios.

Com a ocorrência, o Departamento de Estado dos Estados Unidos enviou o diplomata Richard Fitzpatrick (que havia estado no Paraguai em 1853), novamente em 1856, para resolver o caso, mas não conseguiu restituir o tratado anterior (1853), e não aceitou a nova proposta do governo paraguaio. A partir disso, o presidente James Buchanan entrou em ação. Conseguiu mobilizar US \$10,000,00 no Congresso, em 1858, para uma nova expedição no país. Nomeou-se William Shubrick ao comando da esquadra do Brasil, e Charles Bowlin para negociar com os paraguaios (FITZGERALD, 1973, p. 75-76).

Dessa forma, reuniram 19 navios oriundos de diversas estações navais norteamericanas, dirigindo-os ao Paraguai, com objetivo declarado de exigir reparação aos danos provocados no incidente, incluindo um pedido formal de desculpas do governo paraguaio, além da restituição dos acordos anteriores ao conflito (FITZGERALD, 1973, p.76).

O historiador Vincent Ponko Jr. (1974) descreve a movimentação da frota dos EUA:

\begin{abstract}
Com dinheiro liberado pelo Congresso, sob autorização do presidente, o Departamento da Marinha enviou uma frota de 19 navios sob comando do oficial de bandeira William B. Shubrick, para levar James B. Bowlin, oficial encarregado dos Estados Unidos, para enfrentar o presidente Carlos López. A frota incluía o Water Witch, levava 2.500 homens e 200 canhões. Page comandou a fragata Salinas, com status de capitão de frota. A expedição saiu de Nova York, em outubro de 1858. (p. 129)
\end{abstract}

Em um mês de negociações, em 1859, conseguiram submeter os paraguaios ao perdão pelos "danos" causados, com indenização de dez mil dólares à família de Samuel Chaney. Reafirmaram o acordo de 1853, com cauções à exploração comercial e navegação dos rios, garantindo o fluxo do caminho para a Bolívia pelo rio Paraguay. Pela restituição dos prejuízos alegados no caso da American Company, Hopkins liderou um longo processo judicial que perdurou a década seguinte ${ }^{47}$.

\footnotetext{
${ }^{46}$ Adoto aqui os números indicados por Ponko Jr., pois ele é um historiador especialista em história naval. Entretanto, os registros variam. Fitzgerald (1973) aponta, ao total 15 navios, 77 canhões, 1.449 marinheiros e 291 soldados.

${ }^{47}$ Fitzgerald (1973, p.77-79) aponta uma perda real da American Company de (U.S.) \$254.489 dólares; exigiram um reembolso de $\$ 935.000$ (máximo), uma demanda mínima de US \$500.000, incluindo o que haviam deixado de ganhar. Na intervenção, López propôs US \$250.000, mas Bowlin partiu sem acerto. Em Washington, em 1860, o norte-americano Cave John encontrou-se com o diplomata
}

Revista Eletrônica da ANPHLAC, ISSN 1679-1061, n.15, p. 79-112, jul./dez. 2013. http://revista.anphlac.org.br/ 


\section{Considerações finais: exílio de um "aristocrata sulista" na Argentina.}

Após a retaliação dos Estados Unidos, Page — que não declarou no relato sua participação na intervenção no Paraguai, ainda que o Water Witch fizesse parte da frota de 19 navios que retornou para concluir a prospecção do estuário do Prata. O texto, Farther explorations in La Plata made in the years 1859 and 1860 under the orders of the United States Government, conformou a segunda parte do relato de viagem. Nessa nova etapa, ele comandou os navios a vapor Argentina e também o Alpha, um navio menor, apropriado para rios de cursos difíceis. Visitaram, especialmente, os rios Vermelho, Pilcomayo e a região de Otuquis, no sentido da Bolívia - exatamente as partes que faltaram prospectar por causa conflito (PAGE, $1871, \mathrm{p} .863)^{48}$.

Enquanto os resultados do rio Vermelho foram positivos - Page chegou a eleger Esquina Grande, a duzentos quilômetros de Salto, como um bom porto para se estabelecer a navegação comercial na região -, não se conseguiu comprovar a navegabilidade do Pilcomayo e nem a ligação das lagoas Oberaba e Guaíba com a Bolívia. (PAGE, 1871, p.711) ${ }^{49}$. Aparentemente, a árida geografia do Chaco - "um mar de mato" nas palavras de Page, com misteriosos alagadiços que se formam, assim como a "hostilidade" das populações indígenas, principalmente, dos guaranis - dessa vez, justificariam as maiores dificuldades da expedição (WOOD, 2000).

Page não encontrou a passagem do Prata para o Amazonas como sonhara, o que faria com que recebesse louros no seu país pelo achado, evitando que a expedição fosse lembrada pelo conflito que envolveu o envio da armada de 19 navios ao Prata.

De qualquer forma, considera-se que parte dos objetivos de Thomas Jefferson Page foram levados a cabo no estuário do Prata: eles mapearam a região e

paraguaio José Bergés; enviaram o caso para resolução internacional entre representantes da Rússia, Prússia e Grã-Bretanha. Mas o presidente Buchanan o levou ao Senado, depois Hopkins renegociou o pagamento na presidência de Abraham Lincoln - que indicou Charles Washburn para resolver o caso. $\mathrm{Na}$ iminente Guerra Civil, esfriaram-se as negociações, mas consideraram enviar nova expedição ao Paraguai. A American Company enviou James B. Bond ao país, em 1861. Em 1862, López faleceu; o caso ficou suspenso por 15 anos, até que após a derrota do Paraguai na guerra enviaram o secretário de Estado Bayard para resolver a questão. Em 1887, o Congresso Nacional barrou uma negociação de $\$ 90.000$ dólares em ouro. Hopkins faleceu em Washington, em 1888, e "O caso, finou-se com ele".

${ }^{48}$ Page menciona ter encontrado Francisco Varnhagen, do Instituto Histórico Geográfico Brasileiro; aparentemente, também prospectavam tais divisas.

49 "Rios ao oeste do Chaco são mais regidos pelo clima dos Andes. Nas chuvas, de outubro a março, inunda-se o Vermelho. O Pilcomayo, pelo contrário, flui baixo nas chuvas, época que se formam esteiros - pântanos e lagoas de vegetação sufocante - que o obstroem e o desviam" (KROEBER, 1967, p.26-27).

Revista Eletrônica da ANPHLAC, ISSN 1679-1061, n.15, p. 79-112, jul./dez. 2013. http://revista.anphlac.org.br/ 
conseguiram firmar alguns acordos comerciais. Entretanto, não encontraram a passagem entre as bacias do Prata e do Amazonas que tanto procuravam. Eles também não tiveram sucesso quanto ao seu projeto de estabelecer uma imigração de famílias sulistas no Amazonas, ou quem sabe para a região do Prata, ainda que, como sabemos, Dom Pedro II tenha acordado para que algumas famílias sulistas norteamericanas imigrassem para o interior de São Paulo, estabelecendo-se nas cidades de Americana e Santa Bárbara do Oeste ${ }^{50}$.

No entanto, os objetivos que Page cumpriu no Prata somente foram finalizados depois da ameaça do uso da força pelos Estados Unidos na região, em evento no qual uma armada foi enviada para submeter o governo paraguaio ao que os Estados Unidos consideravam como leis internacionais. Leis que, como se sabe, haviam sido ditadas na Europa, mas às quais nem todos os países haviam aderido. Muitos, inclusive, podiam aderir ao tratado de navegação dos rios quando interessava, ou rechaçá-lo quando interesses estivessem ameaçados. Esse foi o caso do Brasil, que defendia o fechamento do rio Amazonas às nações estrangeiras, mas lutava pela abertura da bacia do Prata em razão do tráfego até o Mato Grosso.

A Guerra Civil (1861-1865) pôs fim à era dos sulistas na U.S. Navy. Page foi comandante da Marinha dos Confederados, na Virginia, baseando-se no rio York, perto de Gloucester County, sua cidade natal. Em 1863, serviu como diplomata e agente secreto na Itália, encarregado de recuperar o encouraçado Stonewall aos Confederados (PONKO JUNIOR, 1974, p.132-133). É significativo que, após a Guerra Civil norte-americana e muito próximo de J.J. Urquiza, Page tenha passado uma temporada na província de Entre Rios, levando com ele dois de seus filhos, Philip Nelson e Frederick John; esse morreu, em 1890, atacado por "selvagens", enquanto prospectava o Pilcomayo (PAGE, 1871, p.723) ${ }^{51}$.

Bem acolhido na Argentina, Page desenvolveu um sistema de defesa entre Buenos Aires, a ilha Martin Garcia e Encenada, utilizando torpedos similares aos desenvolvidos na Guerra Civil nos Estados Unidos. Em 1875, junto a Hunter Davidson, também da Virginia, criou a Divisão Argentina de Torpedos. Contratado pelo governo argentino, trabalhou na construção de quatro navios na Grã-Bretanha.

\footnotetext{
${ }^{50}$ Sobre essa imigração de Confederados para o interior de São Paulo, consultar OLIVEIRA (1995).

${ }^{51}$ As boas relações de Page com Urquiza perduraram; dele recebeu terras para cuidar e meios para cultivá-las. Ao fim do seu relato de viagem, ele menciona o conselho do amigo para se aposentar em Entre Ríos.
}

Revista Eletrônica da ANPHLAC, ISSN 1679-1061, n.15, p. 79-112, jul./dez. 2013. http://revista.anphlac.org.br/ 
Passou o final da vida na Itália, já cego. Faleceu em Roma, em 1899, aos 92 anos $^{52}$.

A melancólica trajetória pessoal de Page mostra o percurso de um "aristocrata" após a derrocada do sul dos Estados Unidos na Guerra Civil. Tanto na Argentina, quanto na Itália e na Inglaterra, Page esteve longe do país que havia imposto aos seus iguais uma "amarga derrota". Junto à sua família, foi expatriado do seu país de origem (GEERDING, 2003).

\section{Fontes:}

PAGE, T.J. La Plata, the Argentine Confederation and Paraguay. Being a narrative of the exploration of the tributaries of the river La Plata and adjacent countries during the years 1853, `54, `55 and `56, under the orders of the United States Government \& Farther Explorations in La Plata - Made in the years 1859 and 1860, under the orders of the United States Government. Washington: Harper and Brothers, 1871. Disponível em: <http://archive.org/stream/cu31924021079565/cu31924021079565_djvu.txt>. Acesso em: 02/09/2013).

Report of the Exploration and Survey of the River La Plata and Tributaries by Thomas J. Page, Commanding the United States Steamer Water Witch to the Secretary of Navy. Washington: Connerlius Wendell Printing, 1856. Disponível em: 〈http://goo.gl/UxMf2f > . Acesso em: 02/09/2013.

La Plata, the Argentine Confederation, and Paraguay. In: North American Review, Harpers magazine, v.0088, n.183, p.430-443, Apr. 1859. Biblioteca da Universidade de Cornwell, Estados Unidos.

ARCHIVO GENERAL DE LA NACIÓN - Museo Histórico Nacional, Buenos Aires, Argentina. Índice Temático General; Correspondencias Navales (Estados Unidos)

MARINA Años 1851-1859, Capitania del Puerto - Copiador de Cartas

Tomo 10.36.10.22 (Folhas numeradas)

ARCHIVO GENERAL JUSTO JOSE DE URQUIZA - Buenos Aires, Argentina. De 1853 a 1859; de TOMO 146 a TOMO 163. (Folhas numeradas)

AFRICAN American Newspapers. THE NATIONAL ERA, Opening of the Rivers Amazon and La Plata. Washington; March 31, 1853. Butler Library, Columbia University.

BOURNE, John. Indian river navigation a report to the comitee of gentlemen formed for the establishment of improved steam navigation upon the rivers of India. Londres: W. H. Allen \& Company, 1849. Butler Library, Columbia University.

DALENCE, Jose Maria. Bosquejo estadistico de Bolivia. Chuquisaca: Ymprenta de Sucre, 1851. Butler Library, Columbia University.

GUZMÁN, Santiago Vaca. Intereses comerciales entre Bolivia y el Plata El Pilcomayo, por Santiago V. Guzmán. Obra escrita por Comisiõn especial de s.e.el señor ex-ministro del interior de la República Argentina, dr. D. Saturnino M. Laspiur

\footnotetext{
${ }^{52}$ Em 1869, Hopkins participou da transposição do rio Vermejo, um dos maiores acidentes ecológicos da região. "No curso inverso Teuco-Vermelho, o rio arroja errônea e anualmente ao Paraguay cerca de 100.000.000 toneladas (62 milhões m³) de areia e argila vermelha" (KROEBER, 1967, p.53).
}

Revista Eletrônica da ANPHLAC, ISSN 1679-1061, n.15, p. 79-112, jul./dez. 2013. http://revista.anphlac.org.br/ 
(1847-1896). Buenos Aires: Imprenta de P.E. Coni, 1880. Butler Library, Columbia University.

HERNDON, William L. Exploration of the valley of the Amazon: made under the direction of the Navy Department. Washington: Sabin Americana - Gale, Cengage Learning, 1854. 3 vols. Versão digital - Oxford: Oxford University Press, 2006. Disponível em <http://goo.gl/xynDEh>. Acesso em: 02/09/2013.

INGERSOLL, Mr. Report of the Memorial of Lieutenant Maury: in behalf of the Memphis Convention in Favor of the Free Navigation of the Amazon River to the Comitee of Foreign Affairs. Washington, U.S. House of Representatives (33rd Congress, Report N95 Ed22 - Miscellaneous), 1854. Butler Library, Columbia University.

MUÑOZ, Juan Ramón. Apuntes cronolójicos de la campaña emprendida sobre el sud por el ejercito libertador al mando de S.E. el Jeneral Ysidoro Belzú. Lo escribió el Oficial Mayor de Guerra J.R.M. La Paz: Imprenta de Beeche, 1848. Butler Library, Columbia University.

WORLD AFFAIRS. A Court of Nations. In: THE ADVOCATE OF PEACE. Boston: American Peace Society, p. 8-10, jan-feb 1859. Disponível em: <http://goo.gl/fOlSP7>. Acesso em: 02/09/2013.

\section{Referências Bibliográficas:}

BANDEIRA, L.A. Moniz. O expansionismo brasileiro e a formação dos Estados na bacia do Prata: Argentina, Uruguai e Paraguai - da colonização à Guerra da Tríplice Aliança. $3^{a}$ ed. Rio de Janeiro: Revan; Brasília: Ed. UNB, 1998.

BEIRED, José Luis Bendicho. Breve história da Argentina. São Paulo: Editora Ática, 1996.

BENTON, Lauren. Law and colonial cultures. New York: Cambridge University Press, 2001.

2009. Geography and Empire. Cambridge: Cambridge University Press,

BORM, Jan. Defining Travel: on the travel book, travel writing and terminology. In: HOOPER, Glen; YOUNGS, Tim. Perspectives on travel writing. Londres: Ashgate, 2004. p. 13-26.

BURNETT, D. Graham. Hidrographic discipline among the Navigators: charting and empires of Commerce and Science in the Nineteenth century Pacific. In: AKERMAS, James. The Imperial Map: cartography and the mastery of Empire. Chicago: University of Chicago Press, 2009. p. 185-257.

CERVO, Amado; BUENO, Clodoaldo. Política externa brasileira. São Paulo: Brasiliense, 2009.

CHIARAMONTE, José Carlos. Cidades, províncias, estados: origens da nação Argentina (1800-1846). São Paulo: Hucitec, 2009.

DORATIOTO, Francisco. Maldita guerra. São Paulo: Companhia das Letras, 2002.

DUROSELLE, Jean Baptiste. Todo império perecerá. Teoria das Relações Internacionais. Brasília: Ed. UNB, 1998.

Revista Eletrônica da ANPHLAC, ISSN 1679-1061, n.15, p. 79-112, jul./dez. 2013. http://revista.anphlac.org.br/ 
FERREIRA, Gabriela Nunes. O rio da Prata e a consolidação do Estado imperial. São Paulo: Hucitec, 2006.

FITZGERALD, Oscar P. Profit and adventure in Paraguay. In: America spreads her sails, BARROW JUNIOR, Clayton R. (Org.). Annapolis: Naval Institute Press, 1973. p. 70-79.

GERDING, Eduardo C. The Confederate Navy and the Argentine Hydrographic survey: Time of the Spar Torpedo. In: The Buenos Aires Herald, n.8, 14 dez. 2003. Disponível em: <http://www.civilwarhome.com/argentinehydrosurvey.htm>. Acesso em: 02/09/2013.

GLENN, Thomas Allen. Some colonial mansions and those who lived in them. Philadelphia: Henry T. Coates \& Co., 1899.

HILL, Lawrence F. Diplomatic relations between the United States and Brazil. Durham: Duke University Press, 1932.

HOBSBAWN, Eric J. A era do capital (1848-1875). São Paulo: Paz e Terra, 2002.

JOSEPH, Gilbert M. Close encounters. Toward a new cultural history of U.S. - Latin American Relations. In: JOSEPH, Gilbert M.; LEGRAND, Catherine; SALVATORE, Ricardo (Orgs.). Close encounters of empire. Writing the cultural History of U.S.Latin American relations. Durham: Duke University Press, 1998. p. 3-46.

JUNQUEIRA, Mary A. Ciência, técnica e as expedições da Marinha de Guerra NorteAmericana, U.S. Navy, em direção à América Latina (1838-1901). In: Varia História, v.23, n.38, p. 334-349, jul-dez 2007.

. Ao sul do Rio Grande - Imaginando a América Latina em Seleções: Oeste, Wilderness e Fronteira (1942-1970). Bragança Paulista: EDUSF, 2000 .

Charles Wilkes, a U.S. Exploring Expedition e a busca dos Estados Unidos da América por um lugar no mundo (1838-1842). In: Tempo. Revista do Departamento de História da UFF, v. 13, p.120-138, 2008.

Os objetivos da circunavegação da U.S. Exploring Expedition

(1838-1842): longitude, mapeamento náutico e instituição das coordenadas geográficas modernas. In: História, Ciências, Saúde - Manguinhos, v.19, n.1, p.2748, jan-mar 2012.

KROEBER, C.B. La navegación de los rios en la história Argentina (1794-1860). Buenos Aires: Paidos, 1967.

LA FUENTE. Ariel de. "Gaúchos", "Motoneros" y "Motoneras". In: GOLDMAN, Noemi; SALVATORE, Ricardo (Orgs.). Caudilhismos Rioplatenses. Nuevas miradas a un viejo problema. Buenos Aires: Eudeba, 2005.

LYNCH, John. As repúblicas do Prata, da independência à Guerra do Paraguai. In: BETHELL, Leslie (Org.). História da América Latina. São Paulo; Edusp - Brasília: Funag, 2001. Volume III: da Independência até 1870. p. 19-72.

LUZ, Nícia. A Amazônia para os negros americanos. Rio de Janeiro: Editora Saga, 1968.

MAGNOLI, Demétrio. O corpo da pátria: imaginação geográfica e política externa no Brasil (1808-1912). São Paulo: Editora UNESP, 1997.

Revista Eletrônica da ANPHLAC, ISSN 1679-1061, n.15, p. 79-112, jul./dez. 2013. http://revista.anphlac.org.br/ 
MEDRANO, Lilia I.Z. de. A livre navegação dos rios Paraná e Uruguai: uma análise do comércio entre o Império Brasileiro e a Argentina (1852-1889). São Paulo, 1989. Tese (Doutorado em História Social) - FFLCH, Universidade de São Paulo. São Paulo, 1989.

MIROW, M.C. A history of private law and institutions in Spanish America. Austin: Texas University Press, 2004.

U.S. The Power of codification in Latin America: Simon Bolívar and the Code Napoleón. In: (Revista) Tulane Journal of International and Comparative Law, Research Paper No. 10-11. Miami: Florida International University Legal Studies, 2000.

PALM, Paulo Roberto. A abertura do rio Amazonas à navegação internacional e o parlamento brasileiro. Brasília : Fundação Alexandre de Gusmão, 2009.

PASSETTI, Gabriel. Indígenas e criollos: política, guerra e traição nas lutas no sul da Argentina (1852-1885). São Paulo, 2005. Dissertação (Mestrado em História Social) FFLCH, Universidade de São Paulo. São Paulo, 2005.

PLATT, D.C.M. Latin America and British trade (1806-1914). Londres: Adam \& Charles Black, 1972.

PONKO JR., Vincent. Ships, seas and scientists - U.S. naval exploration and discovery in the nineteenth century. Annapolis: Naval Institute Press, 1974.

PRADO, Maria Lígia C. América Latina no século XIX. tramas, telas e textos. São Paulo: Edusp, 1999.

PRATT, Mary Louise. Os olhos do Império - Relatos de viagem e transculturação. São Paulo: EDUSC, 1999.

RICERCHIA, Ricardo. Viajeros: ilustrados y românticos en la imaginación nacional. Buenos Aires: Troquel, 2005.

ROMANACH, Alfredo B.; ROQUE, Julio Rafael Contreras. El Paraguay en 1857. Un viaje inédito de Aimé Bonpland. Assunción: Servilibro, 2006.

SAID, Edward W. Cultura e imperialismo. São Paulo: Companhia das Letras, 1995.

SALVATORE, Ricardo D. The enterprise of knowledge: representational machines of informal empire. In: LEGRAND, Catharine C.; SALVATORE, Ricardo D. (Orgs.). Close encounters of empire: writing the cultural history of. U.S. - Latin American relations. Durham: Duke University Press, 1998. p. 71-81.

Imágenes de un Império. Estados Unidos y las formas de representación de America Latina. Buenos Aires: Editorial Sudamerica, 2006.

SAMPAIO, Maria Clara S. Fronteiras negras ao sul. A proposta dos Estados Unidos de colonizar a Amazônia brasileira com afrodescendentes norte-americanos na década de 1860. São Paulo, 2009. Dissertação (Mestrado em História Social) - FFLCH, Universidade de São Paulo. São Paulo, 2009.

SANTOS, Cláudio Villafañe G. O Brasil entre a América e a Europa: o Império e o interamericanismo. São Paulo: UNESP, 2004.

SARAIVA, José Flávio Sombra. Relações internacionais dois séculos de história. Rio de Janeiro: FUNAG, 2001.

SCHMITT, Carl. The Nomos of the Earth in the International Law of jus publicum

Revista Eletrônica da ANPHLAC, ISSN 1679-1061, n.15, p. 79-112, jul./dez. 2013. http://revista.anphlac.org.br/ 
Europaeum. Nova York: Telos Press, 2003.

SCOBIE, James R. La lucha por la consolidación de la nacionalidad Argentina (1852-1862). Buenos Aires: Libreria Hachete, 1964.

SLAUGHTER, Anne Marie. The impact of international law on international cooperation: theoretical perspectives. New York: Cambridge University Press, 2004.

SPROUT, Harold; SPROUT, Margaret. The rise of American naval power (17761918). Annapolis: Naval Institute Press, 1966.

SCHROEDER, John H. Shaping a maritime empire - The commercial and diplomatic role of the American Navy (1829-1861). Westport: Greenwood Press, 1943.

SHUMWAY, Nicolas. La invención de la Argentina. Historia de uma idea. Buenos Aires: Emecé Editores, 1993.

TERNAVASIO, Marcela. El pensamiento de los Federales. Buenos Aires: Editorial El Ateneo, 2009.

TODOROV, Tzvetan. A viagem e seu relato. In: Revista de Letras da UNESP, v.46, n.1, p. 231-244, 2006.

. As estruturas narrativas. São Paulo: Perspectiva, 1970.

WATSON, Adam. A evolução da sociedade internacional: uma análise histórica comparativa. Brasília: Editora Universidade de Brasília, 2004.

WHEATON, Henry; PHILIPSSON, Coleman. Elements of International Law. Boston: Little, Brown, and Company, 1866. Disponível em: 〈http://goo.gl/dNUOs2〉. Acesso em: 02/09/2013.

History of the Law of Nations in Europe and America: from the earliest times to the treaty of Washington, 1842. In: WHEATON, Henry L.L.D., Modern Law of Nations - freedom of navigation of the great rivers. Dublin: WM. \& A. Gould \& Co. Albany, 1845. p. 498-516. Disponível em 〈http://goo.g1/HHPxy0 $>$. Acesso em: 02/09/2013.

WOOD, Robert D. Page, Thomas Jefferson. American National Biography Online. American Council of Learned Societies. Oxford: Oxford University Press, 2000.

Revista Eletrônica da ANPHLAC, ISSN 1679-1061, n.15, p. 79-112, jul./dez. 2013. http://revista.anphlac.org.br/ 